\title{
Emergence of Nanoplastic in the Environment and Possible Impact on Human Health
}

\author{
Roman Lehner, ${ }^{\dagger}$ Christoph Weder, ${ }^{\dagger}$ Alke Petri-Fink, ${ }^{\dagger, \ddagger}{ }^{\dagger}$ and Barbara Rothen-Rutishauser* ${ }^{\dagger}{ }^{\dagger}$ \\ ${ }^{\dagger}$ Adolphe Merkle Institute, University of Fribourg, Chemin des Verdiers 4, 1700 Fribourg, Switzerland \\ ${ }^{\ddagger}$ Chemistry Department, University of Fribourg, Chemin du Musée 9, 1700 Fribourg, Switzerland
}

\begin{abstract}
On account of environmental concerns, the fate and adverse effects of plastics have attracted considerable interest in the past few years. Recent studies have indicated the potential for fragmentation of plastic materials into nanoparticles, i.e., "nanoplastics," and their possible accumulation in the environment. Nanoparticles can show markedly different chemical and physical properties than their bulk material form. Therefore possible risks and hazards to the environment need to be considered and addressed. However, the fate and effect of nanoplastics in the (aquatic) environment has so far been little explored. In this review, we aim to provide an overview of the literature on this emerging topic, with an emphasis on the reported impacts of nanoplastics on human health,

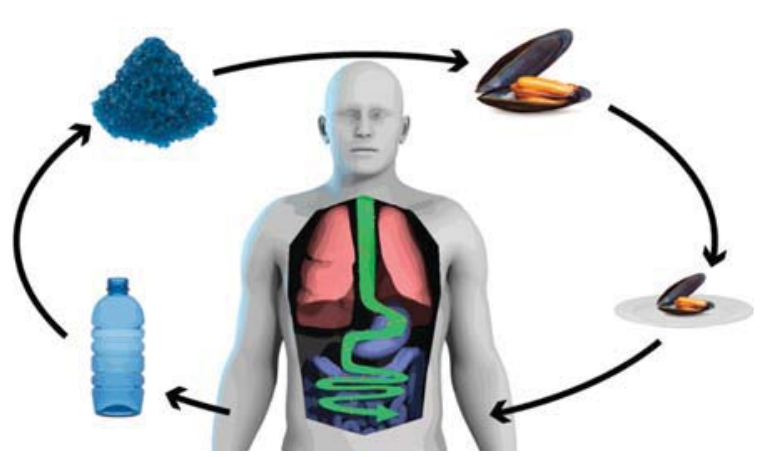
including the challenges involved in detecting plastics in a biological environment. We first discuss the possible sources of nanoplastics and their fates and effects in the environment and then describe the possible entry routes of these particles into the human body, as well as their uptake mechanisms at the cellular level. Since the potential risks of environmental nanoplastics to humans have not yet been extensively studied, we focus on studies demonstrating cell responses induced by polystyrene nanoparticles. In particular, the influence of particle size and surface chemistry are discussed, in order to understand the possible risks of nanoplastics for humans and provide recommendations for future studies.
\end{abstract}

\section{INTRODUCTION}

Synthetic polymers are one of the most important classes of materials of the 21 st century and impact our society and daily life in ways that cannot be overestimated. ${ }^{1}$ The properties of polymers are directly linked to their macromolecular architectures, which can readily be varied in a broad parameter space. As a result, a plethora of synthetic polymers have been developed that cover a broad range of attractive mechanical and other characteristics, including many property combinations that cannot be accessed with naturally occurring polymers such as proteins and cellulose. ${ }^{2}$ The large family of synthetic polymers has traditionally been classified into four groups, namely, (i) thermoplastic polymers or "plastics", i.e., polymers that melt above a specific temperature and can be shaped before solidification upon cooling; (ii) thermosetting polymers or "thermosets", which are provided as (normally liquid) precursors and are irreversibly cured after shaping through a chemical reaction into an infusible, insoluble polymer network; (iii) elastomers; and (iv) synthetic fibers. ${ }^{3}$ Strictly speaking, only group (i) and subsets of groups (iii) and (iv) display thermoplastic character and should thus be referred to as "plastics". However, as an overwhelming majority of polymer particles in the environment stem indeed from thermoplastic materials, the environmental science community has adopted the practice of referring to all polymers as "plastics"; we follow this convention herein as well. Polymers are still mainly derived from petroleum-based raw materials (although there is an increasing trend toward using biobased feedstocks), ${ }^{4}$ and their immense utility is based on their vast range of chemical and physical properties that can be accessed and their low production and processing costs. This makes polymeric materials useful for manifold applications that range from packaging materials to toys and sporting goods to medical devices and construction materials. ${ }^{5-7}$ Commercially used polymers are always formulated with additives such as stabilizers, flame retardants, plasticizers, fillers, and pigments, which contribute to the overall materials properties. ${ }^{8}$ Although additives are typically present in much smaller amounts than the polymer, they are not necessarily benign and can have an adverse effect on the environment. ${ }^{9}$ The production of polymers, including thermoplastics, thermosets, and elastomers, as well as biodegradable and biobased plastics, has increased significantly over the past 60 years (Figure 1). In 2016, around 335 million metric tons of polymers used as plastics were produced worldwide, representing trillions of dollars in terms of global economic returns, with China being the leading producer. ${ }^{10}$

Growing production also leads to an increase of plastic waste and, unfortunately, also promotes widespread accumulation in 


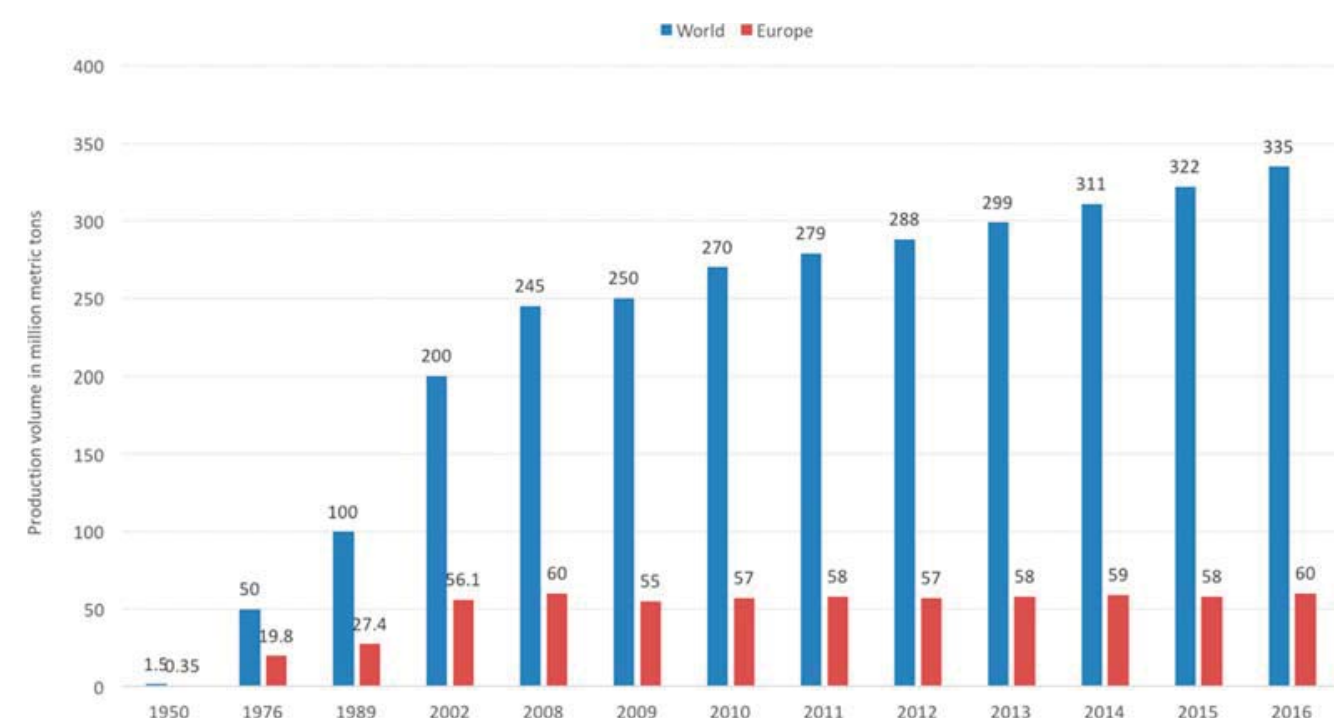

Figure 1. Polymer production worldwide and in Europe, including thermoplastics, polyurethanes, and other polymers (thermosets, adhesives, coatings, and sealants) but not polyethylene terephthalate (PET), polyamide (PA), polypropylene (PP), or polyacrylic fibers. The growth rate of polymer production in Europe has stabilized in the past decade, which is related to the effects of the economic crisis of 2007-2008, as well as higher energy and raw material prices leading to higher product prices and decreasing competitiveness with the flourishing Middle Eastern plastics industry. Numbers adopted from PlasticEurope. ${ }^{11}$

the environment, where the material can become brittle and start to fragment. In the environment the degradation of macroscopic plastic objects $(>5 \mathrm{~mm})$ into smaller pieces, often referred to as microplastics, typically occurs by a combination of chemical and physical processes that notably can involve photodegradation, oxidation, hydrolytic degradation, and mechanical disintegration. These processes are collectively referred to as weathering and, depending on the polymer type and morphology, can differ significantly. ${ }^{12,13}$ Photodegradation caused by the ultraviolet (UV) portion of sunlight generally initiates the weathering process; this radiation is capable of breaking chemical bonds in synthetic polymers. ${ }^{14}$ The process affects not only the polymers themselves but also additives implemented within the materials, resulting in changes in their chemical structure and physical properties. Oxygen can increase the absorption of UV radiation by the formation of a complex with conjugated unsaturated hydrocarbons, thereby accelerating the degradation process. ${ }^{15}$ In addition, polymers such as polyesters or polyamides can also be degraded by hydrolysis, i.e., the cleavage of ester or amide bonds by reaction with water. ${ }^{16,17}$ These chemical degradation processes cause a reduction of the polymer molecules' molecular weight. Eventually this leads to a reduction of mechanical strength and in many cases an increased absorption of water, which causes a further reduction of the mechanical properties and creates bulk and surface stress gradients, which eventually lead to cracking of the material. External mechanical forces also contribute to the fragmentation into smaller pieces, whose dimensions gradually diminish over time. The degraded plastic pieces form a highly heterogeneous collection, varying in size, shape, and density as well as the chemical composition of the specific material.

Newest observations studying the degradation of polyethylene microplastic pellets have shown that already an exposure time of 8 weeks in artificial seawater induces severe microcracking of the pellets surfaces, which, in combination with mechanical forces, can break down the material into smaller sized particles. ${ }^{18}$ Further studies also revealed the formation of nanosized polystyrene particles after 4 weeks of exposure in a weathering chamber. ${ }^{19}$

Several studies have been published in the past few years estimating the mass of the overall global plastic waste as well as the mass of plastic waste entering our oceans (Figure 2), which are considered to be the global ecosystem that is mostly affected by plastic waste. In 2009, Barnes et al. ${ }^{20}$ estimated that plastic materials constitute $10 \%$ of the total discarded waste. Jambeck et al. $^{21}$ presented numbers in the range of

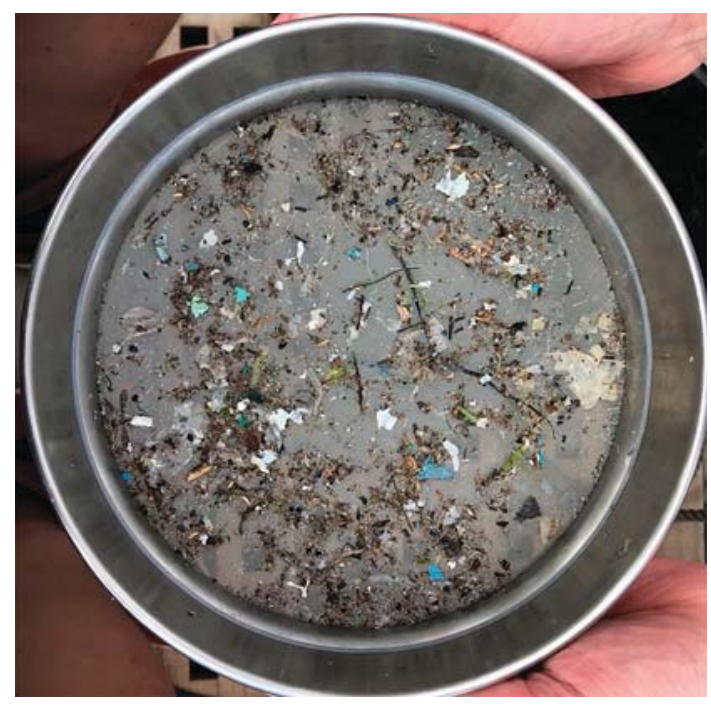

Figure 2. Plastic sample taken from an expedition in the Ligurian Sea in May 2018 by the "Sail and Explore Association" using a manta trawl during $30 \mathrm{~min}$ with a mesh size of $0.3 \mathrm{~mm}$. The Mediterranean Sea represents one of the most polluted seas worldwide with nearly four times higher concentrations of microplastic fragments compared to the North Pacific Gyre and a record-breaking number of 1.25 million microplastic fragments per square kilometer floating. ${ }^{53}$ Reprinted with permission from Sail and Explore Association, Copyright 2018. 
4.8-12.7 million tons of mismanaged plastic waste that was generated in 192 coastal countries and discarded into the oceans in the year 2010. In addition, based on data collected in 24 expeditions conducted during 2007-2013, Eriksen et al. ${ }^{22}$ reported that a minimum of 5.25 trillion plastic particles with a weight of up to 270,000 tons are floating in the world's oceans. Another study reported the number of small plastic particles (nominally $<200 \mathrm{~mm}$ ) to be in the range of $15-51$ trillion, with a collective weight of 93,000 to 236,000 tons, which corresponds to approximately $1 \%$ of the global plastic waste entering the oceans in the year $2010 .^{23} \mathrm{~A}$ recent study from 2018 predicted, using data received from multivessel and aircraft surveys in the so-called "Great Pacific Garbage Patch", that at least 79 thousand metric tons of ocean plastic are floating inside an area of 1.6 million $\mathrm{km}^{2}$, which correlates to numbers 4-16 times higher than previously reported. ${ }^{24}$ Other studies have also proven the occurrence and accumulation of large plastic items in the deep sea, ${ }^{25-27}$ and recently published data show that plastic objects have been ingested by animals of the benthic zone, assuming a sedimentation behavior of the plastic particles. $^{28,29}$ Sedimentation of plastic particles is only possible if the density of plastics is higher than that of seawater (which is the case for roughly a third of all polymers produced) or if they become negatively buoyant by the formation of biofilms and adherence to other particles. ${ }^{30-33}$ The smaller the particles are, the faster they can reach their critical sinking density. ${ }^{34}$ Plastic particles are also deliberately added to personal care products. ${ }^{35}$ A threat that has thus far been underestimated is the impact of microplastics in soils, sediments, and freshwater on the terrestrial ecosystem. ${ }^{36}$ Research has only recently begun in this direction, as an estimated $80 \%$ of microplastic pollution in the oceans originates from land. ${ }^{37,38}$

In the past decade, much attention has been paid to the formation of microplastics. The exact definition of these particles differs but generally includes particles with dimensions between $1 \mu \mathrm{m}$ and $5 \mathrm{~mm} .{ }^{39}$ The first small plastic particles $(<5 \mathrm{~mm})$ were detected in open waters in the 1970s. ${ }^{40,41}$ Recent studies confirmed the expectation that the degradation process of plastic particles does not stop at the micrometer level and that plastic microparticles continue to disintegrate to form plastic nanoparticles. ${ }^{19,42,43}$ Such nanoparticles usually exhibit different chemical and physical properties than macroscopic objects based on the same material. ${ }^{44}$ In addition, their interactions with living organisms can also greatly differ. ${ }^{45}$ Thus, the differences between microand nanoplastics are not trivial, and the interactions of nanoplastics with the environment and organisms are a specific concern. ${ }^{46}$ Like plastic microparticles, nanoplastics can adsorb and carry hydrophobic chemicals that have a potential biological and toxicological impact on the environment, such as polychlorinated biphenyls (PCBs) released from objects like electrical devices, inks, paints, or the pesticide dichlorodiphenyltrichloroethane (DDT) ${ }^{47-49}$ A clear understanding of the interaction of nanoplastics with the environment, especially with living organisms, is important to assess possible health hazards, because nanoplastic particles can react differently than their micronsized counterparts. However, current research aimed at addressing the effects of plastic is focusing mainly on aquatic systems and only limited data are available regarding the impact of nanosized plastic particles on human health, ${ }^{50,51}$ although their formation in the environment is increasing and thus also the possible transfer to humans via the food chain. ${ }^{52}$
It is apparent that the pollution of oceans with plastic has become a major environmental issue. Although the long-term impact of micro- and nanoplastics in the (aquatic) environment is still difficult to predict, this aspect might prove to be a significant challenge to our society. ${ }^{54}$ The purpose of this review is to provide an overview of current knowledge specific to nanoplastics and their impact on the environment and human health. We briefly discuss sources and nanoplastic formation in the aquatic environment and the impact of nanoplastics on aquatic species and human exposure which is most likely via seafood. Furthermore, we will focus on possible entry routes of nanoplastics into the human body focusing on the cellular level.

\section{SOURCES AND FATE OF PLASTIC IN THE ENVIRONMENT}

The accumulation of plastics and their degradation products in the environment has continuously increased in recent decades, which is unsurprising given that $50 \%$ of plastic products are produced for single-use applications and are soon discarded. ${ }^{55}$ Discarded packaging plastics account for a significant part of the total solid waste that ends up in landfills, where, depending on their composition, they remain unchanged or may degrade into fragments upon microbial heat production and further biodegrade to carbon dioxide and water. ${ }^{56}$ Macroplastics represent the main source of plastic litter. Once in the environment they can lead to entanglement and, despite their size, being ingested and retained by various species, including seabirds, fish, and cetaceans, which then often die from related causes such as starvation. ${ }^{57,58}$ Microplastic particles affect an even greater number of organisms, including primary consumers of the food chain such as zooplankton, bivalves, and small fish. ${ }^{59-61}$ It has been shown that (fragments of) textile fibers with dimensions in the micrometer range, which are disengaged from clothes during washing, are not removed by the filter systems of wastewater treatment plants and therefore end up in the environment. ${ }^{62}$ In addition, personal care products such as toothpastes and facial scrubs often contain polyethylene-based microplastic particles which then end up in the wastewater. ${ }^{63}$ The presence of microplastics has been reported all around the globe, from polar regions frozen in arctic ice to the open water around the equator, and from coastal areas down to the deep sea. ${ }^{30,64}$ The process of plastic degradation progresses with increased time in the environment and may eventually lead to the formation of nanoparticles. ${ }^{65}$ For example, a recent study by Lambert et al. demonstrated the formation of plastic nanoparticles under laboratory conditions when disposable polystyrene coffee cup lids were exposed to UV light. ${ }^{19}$ This observation supports the notion that wherever polymeric objects are released in the environment, the degradation to nanoplastic should a priori be considered. At the same time, it is clear that the degradation pathways of different polymer types can vary significantly-while some polymers degrade into nanoparticles, others are known or can be expected to form water-soluble fragments. From experimental observations made so far, it can be estimated that plastic nanoparticles can be released into the environment as "primary", i.e., intentionally manufactured particles for industrial purposes, e.g., paints, adhesives, electronics, and cosmetics, and/or emerge as "secondary particles" as a result of the degradation of larger plastic objects. ${ }^{66-68}$ Primary nanoplastics used in households and industry are most likely 
not being collected by the wastewater treatment facilities and are thus discharged as sewage into the aquatic environment.

However, our current knowledge of nanoplastics in the environment is still very limited and only a few scientific publications are available. In addition, the literature remains inconsistent about the categorization of the particle sizes. ${ }^{39} \mathrm{~A}$ number of studies have set the upper size limit of nanoplastics at either 100 or $1000 \mathrm{~nm}$. A recent publication by Gigault et al. proposes an appropriate definition of nanoplastics on the basis of physical and chemical properties. According to the authors, a nanoplastic is defined as "particles within a size ranging from $1 \mathrm{~nm}$ up to $1000 \mathrm{~nm}$ resulting from the degradation of industrial plastic objects and can exhibit a colloidal behaviour".99 One could, however, recommend the use of the official EU recommendation on the definition for nanomaterials, i.e., "A natural, incidental or manufactured material containing particles, in an unbound state or as an aggregate or as an agglomerate and where, for $50 \%$ or more of the particles in the number size distribution, one or more external dimensions is in the size range of $1 \mathrm{~nm}-100 \mathrm{~nm}$ " ${ }^{70}$ Another difficulty is that currently no detection method can confirm the presence of nanoplastic components in the environment. $^{71}$

2.1. Effects of Nanoplastics on the Aquatic Environment. Numerous studies have shown that macro- and microplastics can have a significant adverse impact on the aquatic environment and have been reported elsewhere in detail. ${ }^{72-74}$ But what are the effects of nanoplastic particles on the aquatic environment?

In recent years several experimental studies using model polystyrene nanoparticles have emphasized that various organisms such as daphnia, mussels, zooplankton, and algae can actively ingest nanoplastic particles or adsorb them to their surfaces. $^{75-78}$

In a laboratory setting, the effects of amino-functionalized polystyrene nanoparticles with a diameter of $50 \mathrm{~nm}$ and concentrations between $1-50 \mu \mathrm{g} / \mathrm{mL}$ have been investigated in the hemocytes of the marine bivalve Mytilus galloprovincialis by Canesi et al. ${ }^{79}$ The hemocytes were exposed to different concentrations of amino-functionalized polystyrene particles, which stimulated an increase in extracellular reactive oxygen species and lead to apoptosis within $1 \mathrm{~h}$ of exposure. This rapid response is in line with the physiological role of hemocytes in cell-mediated immunity. Sun et al. showed that nanoplastic particles at a size of $50 \mathrm{~nm}$ and a concentration of $80 \mathrm{mg} / \mathrm{L}$ induce toxicity related to oxidative stress toward marine bacterium Halomonas alkaliphila compared to microplastic particles at a size of $1 \mu \mathrm{m}$. Furthermore, amine-modified $50 \mathrm{~nm}$ polystyrene nanoparticles induced higher oxidative stress toward bacteria than that induced by nonmodified particles. ${ }^{80}$ The toxicity of amine-modified polystyrene particles was further proven by Tallec et al. Exposure of $50 \mathrm{~nm}$ polystyrene nanoparticles at concentrations between 0.1 and $25 \mu \mathrm{g} / \mathrm{mL}$ to Pacific oysters (Crassostrea gigas) showed an increase in toxicity for both gametes and embryos in comparison to nonmodified particles. Overall, their data highlight that exposures to polystyrene nanoparticles may have deleterious effects on planktonic stages of oysters. ${ }^{81}$ Brandts et al. investigated the effects of polystyrene nanoparticles, individually or combined with carbamazepine, on the mediterranean mussel Mytilus galloprovincialis. Carbamazepine is among the most commonly detected drugs in the environment and may adsorb onto nanoplastics. For this purpose, mussels were exposed for $96 \mathrm{~h}$ to a range of concentrations of $110 \mathrm{~nm}$ polystyrene particles (from 0.05 up to $50 \mathrm{mg} / \mathrm{L}$ ), to carbamazepine $(6.3 \mu \mathrm{g} / \mathrm{L})$ alone and to a mixture of polystyrene + carbamazepine $(0.05 \mathrm{mg} / \mathrm{L}+6.3 \mu \mathrm{g} / \mathrm{L})$. Observations of different biomarkers from the digestive glands, gills, and hemolymph were conducted. After exposure to polystyrene, carbamazepine, and their mixture, clear evidence for genotoxicity was found in hemocytes as well as significant downregulation in gene expression after combined exposure of polystyrene and carbamazepine. Moreover, it could be shown that even at the lowest concentrations tested, polystyrene nanoparticles can induce oxidative damage. ${ }^{82}$ Della Torre et al. demonstrated that the accumulation of $50 \mathrm{~nm}$ amino-modified polystyrene nanoparticles at tested concentrations of $1-50 \mu \mathrm{g} /$ $\mathrm{mL}$ in sea urchin embryos induced changes in gene expression and embryotoxicity. ${ }^{83}$ A recent study investigated the effects of $75 \mathrm{~nm}$ polystyrene nanoparticles at concentrations between 10 and $400 \mathrm{mg} / \mathrm{L}$ on the physiological changes (i.e., survival) and expression levels of stress defense genes of Daphnia pulex. The expression of the gene encoding the energy-sensing enzyme AMPK (adenosine monophosphate-activated protein kinase) was influenced by the nanoplastic in different age groups. Thus, age must be considered as a factor of great relevance when predicting toxic effects. ${ }^{84}$

Effects of nanoplastic on the innate immune system of fish have been reported by Greven et al., indicating that the stress response to polystyrene and polycarbonate nanoparticles could stimulate the degranulation of primary granules, oxidative burst activity, and neutrophil extracellular trap release. ${ }^{85}$ Experiments with zebrafish revealed that after 7 days of exposure to fluorescent polystyrene nanoparticles with a diameter of $70 \mathrm{~nm}$ and at concentrations between 0.025 and $0.2 \mu \mathrm{g} / \mu \mathrm{L}$, inflammation and lipid accumulation in the liver occurred. ${ }^{86}$ Marques-Santos et al. investigated the effect of $50 \mathrm{~nm}$ aminomodified polystyrene particles at concentrations of $1-25 \mu \mathrm{g} /$ $\mathrm{mL}$ on sea urchin Paracentrotus lividus immune system cells (coelomocytes) in the presence of celomic fluid and at different particle concentrations. Amino-modified polystyrene particles acquired a protein corona once incubated with celomic fluid, dominated by the toposome precursor protein, which triggers particle-coelomocytes interactions and toxicity. ${ }^{87}$

Wegner et al. showed that $30 \mathrm{~nm}$ polystyrene nanoparticles, that were tested at concentrations of $0.1-0.3 \mathrm{~g} / \mathrm{L}$, have an adverse effect on the feeding behavior of the blue mussel Mytilus edulis because of a reduced filtering activity in the presence of the particles. ${ }^{88}$ Pitt et al. investigated the potential toxicity of polystyrene nanoparticles in developing zebrafish (Danio rerio) and characterized the uptake and distribution of the particles within embryos and larvae. Embryos at $6 \mathrm{~h}$ postfertilization were exposed to $51 \mathrm{~nm}$ polystyrene nanoparticles (approximately $1 \mathrm{mg} /(\mathrm{g}$ of fish)) up to $120 \mathrm{~h}$ postfertilization. At $24 \mathrm{~h}$ postfertilization the particles could be found in the yolk sac and had migrated to the gastrointestinal tract, gallbladder, liver, pancreas, heart, and brain between 48 and $120 \mathrm{~h}$ postfertilization. In addition, it could be seen that the particles altered larval behavior as evidenced by swimming hypoactivity in exposed larvae. ${ }^{89}$ An initial study of the effect of nanoplastic particles delivered through the food chain (algaezooplankton-fish) on the brain tissue of fish was conducted by Mattsson et al. They showed that $52 \mathrm{~nm}$ positively charged amino-modified polystyrene nanoparticles above $0.075 \mathrm{~g} / \mathrm{L}$ are toxic to Daphnia magna and that fish eating nanoplastic 
contaminated Daphnia showed behavioral disorders. Furthermore, polystyrene nanoparticles were detected in the brain tissue of all fed fish using hyperspectral imaging. This finding proves for the first time that plastics nanoparticles can be transported across the blood-brain barrier in fish. ${ }^{90}$

The majority of the mentioned studies showing an adverse effect on different organisms were conducted using aminomodified polystyrene nanoparticles and concentrations which are not environmentally relevant as they are all too high. The amino modification induces a positive surface charge to the particles, which is experimentally interesting to test charge effects. Nevertheless, it is well-known from the field of nanomedicine that aminated surfaces are mainly used for coupling to, e.g., proteins or antibodies and that the positive charge of cationic polymers can facilitate cellular uptake and endolysosomal escape, thereby overcoming major cellular barriers and consequently increasing the possibility for further intracellular reactions. ${ }^{91}$ The most important class of plastic materials containing nitrogen in the form of amides is polyamides. These can be hydrolyzed to afford amines, but it is not entirely clear to what extent the amines remain intact (depending on the type, they may be protonated and oxidized). However, polyamides are not widely used as packaging materials, and therefore amine-containing nanoplastic particles stemming from polyamides are not expected to be a major environmental factor.

Additionally, nanoplastic particles in the environment will most probably interact with their surroundings, leading to homo- or heteroagglomerates composed of different constituents, due to the size and hydrophobic properties of the materials. ${ }^{92,93}$ This might lead to the formation of a surface corona of various adsorbed molecules evoking a change of the physical and chemical parameters as well as a reduced surfacearea-to-volume ratio, thus changing their biological activity and maybe affecting their sedimentation properties. ${ }^{94}$ These facts have to be considered for experimental approaches regarding influences on aquatic systems, in order to mimic natural conditions as closely as possible.

For nanoplastics, uptake by several aquatic species, the adsorption of hydrophobic persistent organic pollutants (POPs), and the leaching of chemicals and POPs have been demonstrated, highlighting their potential biological and toxicological impacts on the environment. ${ }^{95}$

However, a number of studies showing adverse effects such as reactive oxygen species production and reproductive malfunctioning upon exposing aquatic organisms to nanoplastics have used concentrations several orders of magnitude higher than concentrations predicted to be environmentally relevant such as $1 \mathrm{pg} \mathrm{L}^{-1}$ to $15 \mu \mathrm{g} \mathrm{L}^{-1}$ for nanoplastics at sizes of about $50 \mathrm{~nm} .{ }^{96}$ Reflecting this fact will help to understand the impact of environmentally relevant nanoplastic concentrations. In addition, there is a lack of knowledge regarding how nanoplastics (and hitchhikers) are transferred up the food chain and how they accumulate and interact with the environment, especially with living organisms. Thus, the impact of a contaminated food chain on humans and the resulting health hazards are not at all clear.

\section{IMPACT OF NANOPLASTICS ON HUMAN HEALTH}

Exposure to nanoplastic might occur via oral inhalation, ingestion, or absorption by the skin in connection with the use of plastic products or unintentional means (Figure 3). Inhalation is likely to be relevant in occupational exposure

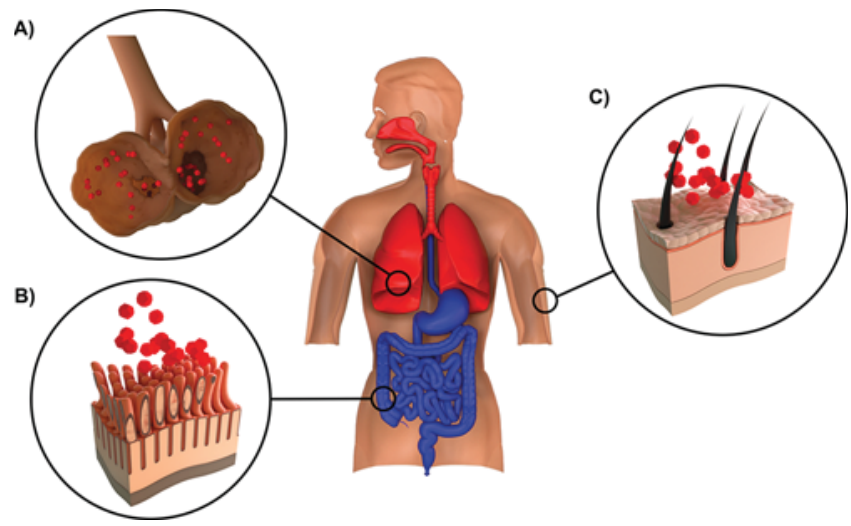

Figure 3. Schematic illustration showing the three major pathways of human exposure to nanoplastics, i.e. via (A) the lung, (B) the gastrointestinal (GI) tract, and (C) the skin.

scenarios that involve nanoplastic-containing aerosols, ${ }^{97}$ whereas potential contact with the skin can occur through the use of personal care products such as nanoplasticscontaining skin care and cleansing products, or contaminated water or air. According to the current knowledge, ingestion of nanoplastic particles is likely to represent the main route of entry, since nanoplastic particles can be ingested by eating seafood or drinking contaminated water. In addition, nanoplastic uptake and accumulation, as well as trophic transfer of nanoplastic within aquatic organisms has been demonstrated under experimental conditions, thus fortifying the possibility that nanoplastics might accumulate in the food chain, and thus result in human exposure. ${ }^{98,99}$ Microplastic particles have already been found in several seafood species, such as fish, shrimps, and bivalves, but also in other foods, such as honey, beer, salt, and sugar. ${ }^{60,100-104}$ Recent studies using FTIR spectroscopy have also shown the existence of microplastics in tap water and bottled water as well as drinking water from groundwater sources. Out of 159 samples of globally sourced tap water, $81 \%$ were found to contain microplastic particles, mainly fibers smaller than $5 \mathrm{~mm}$ with an overall mean of 5.45 particles/L. ${ }^{105}$ From a total of 259 individual bottles of water from 11 different brands and 27 different lots, 93\% showed signs of microplastic contamination with an average of 10.4 particles/L. ${ }^{106}$ Analysis of groundwater from the northwestern part of Germany revealed that an overall mean of 0.7 microplastics $/ \mathrm{m}^{-3}$ can be found. ${ }^{107}$ These studies reiterate that the occurrence of nanoplastics in various food products cannot be ruled out. Unfortunately, there are currently no routine methods available that permit detection of nanoplastics in foods, and as a result, no data are available that go beyond the above-mentioned research works.

Human health might also be affected due to the transfer or leaching of chemical additives from the plastic material itself. Within the plastic manufacturing process, chemicals such as plasticizers, pigments, or stabilizers are added to give the desired properties of the final product, e.g., their flexibility, color, and stability. Nowadays, thousands of different chemicals are currently used for these purposes, and it is known that some of these chemicals can leach out during the product life cycle into the environment, leading to endocrine disruption or acute toxicity when exposure to organisms occur. ${ }^{108}$ The same considerations apply for the monomers (i.e., the chemical building blocks) used to manufacture the polymers in the first place (of which small amounts may 
remain in the polymers) and the products formed by the chemical degradation of polymers. The most prominent example of a leaching monomer is bisphenol A (BPA), which is used for the preparation of polycarbonate and certain epoxy resins. It has been shown that BPA causes adverse effects in humans due to its estrogenic activity, including several metabolic diseases as well as reproductive and developmental effects. ${ }^{109-111}$ In particular, polycarbonate drinking bottles used for newborns showed high leaching of BPA. Newborns have a much higher risk than adults since a higher internal body burden is expected, expressed as concentration in blood/ plasma, due to increased absorption or decreased elimination compared to the internal body burden of adults. ${ }^{112}$

3.1. Entry Routes of Nanoplastics into the Human Body. Three major exposure pathways to nanoplastics are possible, i.e., via the lung, the gastrointestinal (GI) tract, and the skin. The lung has a very large alveolar surface area of ca. $150 \mathrm{~m}^{2}$, with a very thin tissue barrier of less than $1 \mu \mathrm{m},{ }^{113}$ allowing nanosized particles to penetrate into the capillary blood system and to distribute throughout the human body. ${ }^{114,115}$ Several studies have shown that exposure to synthetic polymers can have an adverse effect on the health if absorbed by the respiratory system. ${ }^{116-118}$ Studies applying polystyrene particles to alveolar epithelial cells in vitro have shown that nanoplastic particles are taken up and that the uptake rate is size-dependent (Figure 4). ${ }^{19-122}$ Recently,

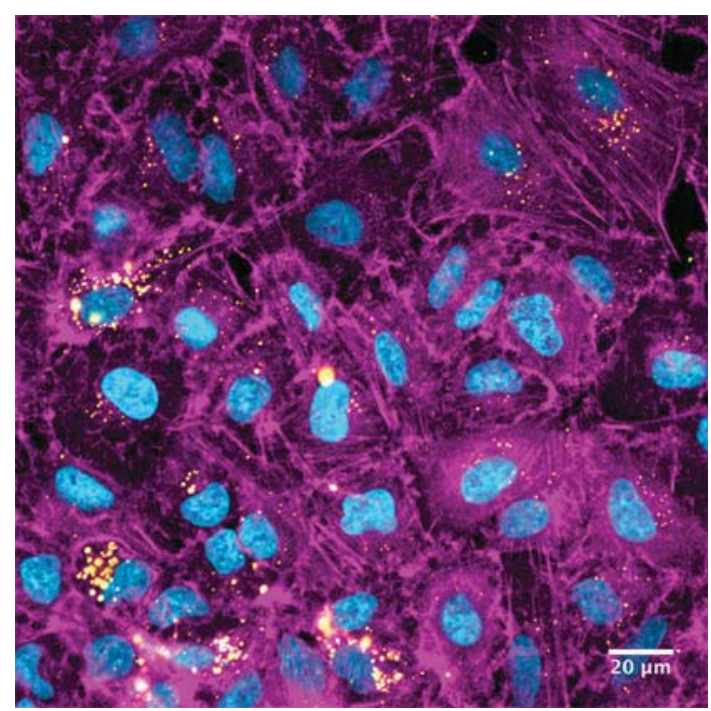

Figure 4. Human lung epithelial cancer cells (A549) labeled for Factin (purple) and the nuclei (blue) showing uptake of $200 \mathrm{~nm}$ amino-modified polystyrene particles labeled with FITC (yellow) after exposure for $24 \mathrm{~h}$.

synthetic fibers in atmospheric fallout in urban areas have been highlighted as a possible source for human exposure to microplastics by inhalation. ${ }^{123}$ Atmospheric fallout of microplastics, collected with a stainless steel funnel, was investigated in two different urban and suburban sites in Paris. About 30\% of particles observed were synthetic fibers with diameters between 7 and $15 \mu \mathrm{m}$ and predominant sizes of $200-600 \mu \mathrm{m}$. Between 2 and 355 particles $/ \mathrm{m}^{2} /$ day, with an average of $110 \pm$ 96 particles $/ \mathrm{m}^{2} /$ day were observed. Fluxes were found to be systemically higher at the urban site than at the suburban site. Rainfall was also shown to have a clear effect on the concentrations observed. ${ }^{123}$ Dris et al. investigated micro- plastic fibers in indoor and outdoor air. Two private apartments and one office were chosen as indoor sites, where a concentration between 1.0 and 60.0 fibers $/ \mathrm{m}^{3}$ was measured, which was significantly higher than the outdoor concentration (between 0.3 and 1.5 fibers $/ \mathrm{m}^{3}$ ). Around $33 \%$ of the fibers they collected indoors were of petrochemicals origin with polypropylene being predominant, while the resting $67 \%$ consisted mainly of cellulose. ${ }^{124}$ However, there are thus far no data available concerning the number or concentration of aerosolized nanoplastics. The numbers presented by the studies of Dris et al. are more than 1000 times lower than the permissible exposure maximum of $5 \mathrm{mg} / \mathrm{m}^{3}$ respirable nuisance dust/( $8 \mathrm{~h}$ working day) established by the U.S. Occupational Safety and Health Administration (OSHA). ${ }^{125}$ This suggests that the concentrations of microplastics found in the air in these studies might be too low to have an adverse effect on human health. Nevertheless, more data are needed, in particular taking into account the physicochemical characteristics of the material as well as their sizes.

Furthermore, Wright and Kelly suggest that human exposure to micro- and nanoplastics through inhalation might occur by the transportation of sea salt aerosols. These aerosols can arise from wave action containing polymer particles of appropriate sizes, which then can be transported by the wind to coastal environments. Another scenario involves the application of wastewater treatment sludge containing plastic particles to agricultural land as a fertilizer. Once the sludge is dried, wind can further transport the plastic particles and distribute them. For further information regarding inhalation exposure of microplastics, we refer readers to Wright and Kelly, ${ }^{50}$ Gasperi et al., ${ }^{126}$ and Prata, ${ }^{97}$ who provide detailed overviews of the topic.

Although the concentration of synthetic polymer particles in the air is usually very low, the GI tract, with its large surface area of ca. $200 \mathrm{~m}^{2}$, represents the primary exposure site for plastic particle uptake. Ingestion and accumulation of nanoplastic particles in the GI tract has been demonstrated in a wide range of aquatic organisms, such as fish, mussels, and also birds. ${ }^{89,98,127-129}$ Human uptake of plastics might occur by intentional swallowing, leading in the worst case to a plastic bezoar, ${ }^{130}$ a rare cause of GI obstruction occurring mainly in people with psychiatric ailments or, more likely, unintentionally via the food chain by the consumption of plasticcontaminated food and drinks or possibly through migration of nanoplastic particles from the packaging materials into food products.

It has been shown that microplastics ingested by fish are poorly absorbed via the GI barrier into the tissue, and gutting of the fish reduces the possibility of consuming microplastic particles. In contrast, polystyrene nanoparticles have been shown to overcome the GI barrier and to translocate into the underlying tissue, as demonstrated by several groups with filter feeders and shellfish. ${ }^{76,88,128}$ Data on the release of nanoplastics from packaging released into food products are currently unavailable; therefore, the exposure to humans cannot be estimated for this method of intake. ${ }^{131}$

Most of our current knowledge regarding nanoplastic and intestine interaction comes from cell culture studies using intestine cells. Several in vitro studies have investigated the internalization and translocation of polystyrene nanoparticles in intestine cell monocultures or even more complex human intestinal cell models. Forte et al. showed that polystyrene nanoparticles with a diameter of $44 \mathrm{~nm}$ accumulate faster and 
more efficiently in the cytoplasm of human gastric adenocarcinoma cells than otherwise identical particles with a diameter of $100 \mathrm{~nm}$. In addition, the $44 \mathrm{~nm}$ particles showed a strong upregulation of the interleukin (IL)- 6 and IL-8 genes, which are involved in gastric pathologies. ${ }^{132}$ Walczak et al. determined the translocation of polystyrene particles with diameters of 50 and $100 \mathrm{~nm}$, having positively and negatively charged as well as uncharged surfaces, in three in vitro intestine cell models of increasing complexity using Caco-2, HT29MTX, and M-cells. Their results showed that both the size and the chemical composition of the particle surface impacts their translocation. The size clearly affected the translocation of the nanoparticles, ranging up to $7.8 \%$ for the $50 \mathrm{~nm}$ and $0.8 \%$ for the $100 \mathrm{~nm}$ particles. However, the surface chemistry seems more important, as the two types of negatively charged $50 \mathrm{~nm}$ NPs had a greater than 30-fold difference in translocation rates. ${ }^{133}$ Mahler et al. suggested that acute oral exposure of positively charged polystyrene nanoparticles can disrupt intestinal iron transport and cellular uptake. ${ }^{134}$

The cellular uptake of nanoparticles is strongly influenced by their interactions with surrounding biological components, such as proteins, phospholipids, or carbohydrates, due to their size, surface chemistry, and charge. ${ }^{135}$ Adsorption of proteins from body fluids on nanoparticle surfaces results in the formation of a so-called "protein corona" around the particle. ${ }^{136}$ Hence, interactions between organs and tissue generally occur with protein-coated-rather than barenanoparticles, likely causing changes in the characteristics and properties of the nanoparticle. Polystyrene nanoparticles have been shown to form protein corona complexes in in vitro GI studies, resulting in increased translocation, ${ }^{137}$ the change of the protein corona composition over time depending on the local environment, ${ }^{138}$ and increased cellular uptake and toxicity. ${ }^{139}$ Furthermore, the protein corona caused the polystyrene nanoparticles to be retained in the gut.

In conclusion, it has been shown that, in contrast to microplastic particles, nanoplastic particles overcome the GI barrier in aquatic organisms and can translocate into the underlying tissue. In addition, polystyrene nanoparticles can translocate the human intestine barrier in vitro. However, the reported studies rely solely on model polystyrene nanoparticles and are not from environmental samples (Figure 5). Other polymers such as PP, PE, and PET are, however, the main polymer material present in the environment. Thus, extrapolations of findings from polystyrene materials to other polymers should be made with caution, and new model studies should be introduced including PP, PE, and PET.

The skin forms a protective barrier against external influences such as physical injuries, chemical agents, or bacteria. Contact of plastics with the skin might occur via the use of cosmetic products containing nanoplastic particles or with nanoplastic-contaminated water. The stratum corneum is the physical barrier of the skin, and due to the hydrophobic properties of the plastic particles, significant nanoplastic uptake through human skin in water is not to be expected. However, possible entry routes include hair follicles, exits of sweat glands, or via injured skin areas. ${ }^{140}$ Skin penetration and resulting tissue distribution of plastics has been studied by AlvarezRoman et al., who applied fluorescent polystyrene particles with diameters of 20 and $200 \mathrm{~nm}$ to a porcine skin tissue model. ${ }^{141}$ Confocal laser scanning microscopy images revealed a higher accumulation of the $20 \mathrm{~nm}$ polystyrene nanoparticles than with the $200 \mathrm{~nm}$ sized particles in the follicular openings,

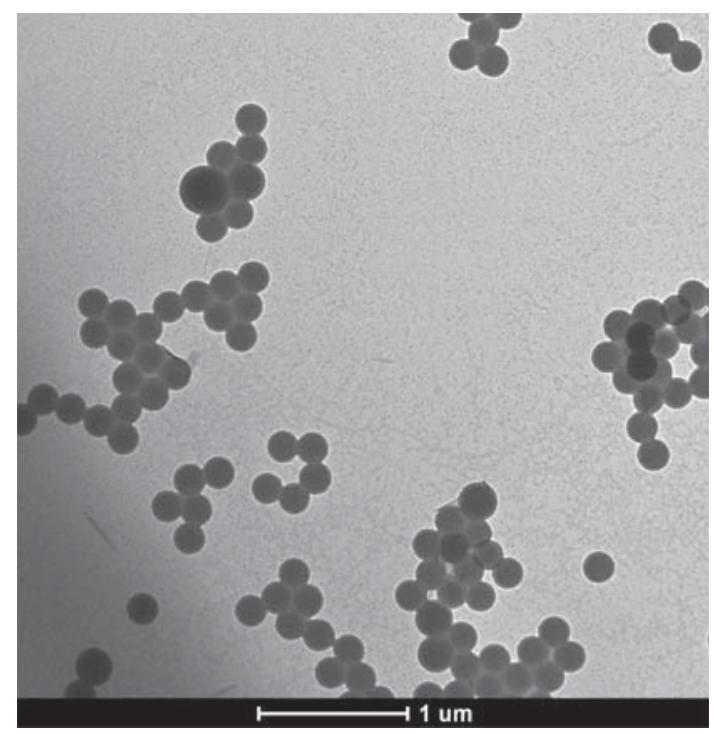

Figure 5. Transmission electron microscopy image showing commercially available spherically shaped polystyrene nanoparticles used for in vitro studies.

whereas neither particle type was found to penetrate into deeper skin tissue, possibly due to the barrier properties of the stratum corneum. These results were confirmed by an additional study conducted by Campbell et al. a few years later, who observed that polystyrene particles with diameters of 20-200 nm penetrate only into the surface layers, approximately $2-3 \mu \mathrm{m}$, of the stratum corneum. ${ }^{42}$ A study conducted by Vogt et al. identified fluorescent polystyrene nanoparticles of a diameter of $40 \mathrm{~nm}$ in the perifollicular tissue of human skin explants pretreated with cyanoacrylate follicular stripping and confirmed uptake by Langerhans cells after transcutaneous application to human skin. ${ }^{143}$ Microbeads used in cosmetics such as scrubs and shampoos are processed by mechanical means that may lead to their fragmentation into potentially more hazardous nanoplastics. In a recent publication, Hernandez et al. tested facial scrubs containing polyethylene microbeads with diameters of $200 \mu \mathrm{m}$ for the presence of nanoplastics. Scanning electron microscopy data revealed nanoparticles ranging in size from $24 \pm 6$ to $52 \pm 14$ $\mathrm{nm}$. The material composition was tested by X-ray photoelectron spectroscopy and Fourier transform infrared spectroscopy, which confirmed that the identified nanoparticles consisted of polyethylene. ${ }^{67}$ The further potential ability of nanoplastics to overcome the skin barrier can be extrapolated from data available from studies using nanoparticles. Skin stress evoked by UV radiation has a widespread effect on the integrity of the skin barrier. An initial in vivo study conducted by Mortensen and colleagues investigated nanoparticle skin penetration of carboxylated quantum dots (QDs) with and without UV exposure. Their results showed qualitatively higher levels of penetration of QD nanoparticles in the UV exposed mice, due to the perturbed expression of tight-junction-related proteins (Zonula occludens-1, claudin-1, and occludin), which promote intercellular adhesion. ${ }^{144}$ The effect that common commercial skin care lotions may have on the penetration of QD nanoparticles into the skin was determined by Jatana et al. In their study, QDs were added to five commercial skin lotions and applied to freshly excised human skin as well as C57BL/6 hairless mice. Their findings suggest that certain ingredients 
(e.g., urea, glycerol, and $\alpha$-hydroxyl acids) found in common commercial skin care lotions can enhance NP penetration into the skin. ${ }^{145}$ In addition, several chemical penetration enhancers have shown their potential to support skin penetration by nanoparticles. ${ }^{146}$ Kuo et al. illustrated the differences between oleic acid, ethanol, and oleic acid-ethanol enhancers for the transport of zinc oxide nanoparticles. The results showed that all three were capable of enhancing the transdermal delivery of zinc oxide nanoparticles. ${ }^{147}$ However, there is currently little evidence that polymeric nanoparticles larger than $100 \mathrm{~nm}$ can penetrate into intact skin. ${ }^{148}$

Once the plastic particles have entered the human body, they may overcome the primary tissue barriers and be transported through the bloodstream to secondary organs. In vitro studies have shown that carboxylated polystyrene nanoparticles can adsorb to, and penetrate into, red blood cells (RBCs) as a result of van der Waals, electrostatic, hydrogen bonding, and hydrophobic forces between polystyrene and the RBCs. ${ }^{149,150}$ This so-called cellular hitchhiking mechanism allows the polystyrene nanoparticles to avoid rapid clearance by the liver and spleen and, therefore, increase their circulation time.

Secondary barriers able to be reached via the bloodstream include the placental barrier and the blood-brain barrier (BBB). Grafmueller and colleagues showed with an ex vivo human placental perfusion model that polystyrene particles with diameters of up to $240 \mathrm{~nm}$ can be taken up by cells of the placental barrier and transported from the fetal to the maternal blood circulation. ${ }^{151}$ The operating translocation mechanism seems likely to be an energy-dependent transport pathway. The $\mathrm{BBB}$ is a highly selective barrier regulating the uncontrolled diffusion of molecules into the brain. However, Yang et al. demonstrated $\mathrm{BBB}$ permeability with polystyrene nanoparticles having a diameter of $20 \mathrm{~nm}$ using an in vivo rat model by implantation of a microdialysis probe into the cerebral cortex of anesthetized rats injected with fluorescent polystyrene nanoparticles. ${ }^{152} \mathrm{~A}$ recent study by Rafiee et al. attempted to assess the neurobehavior of rats exposed to pristine polystyrene nanoparticles upon oral exposure. They investigated different concentrations of 25 and $50 \mathrm{~nm}$ polystyrene particles $(1,3,6$, and $10 \mathrm{mg}$ of polystyrene nanoparticles/(kg of body weight)/ day) administrated orally with adult male Wistar rats for 5 weeks. No statistically significant behavioral effects were observed in any of the tests performed. ${ }^{153}$

In conclusion, it has been shown by in vitro and in vivo studies that micro- as well as nanoplastic particles might be taken up into the human body and can overcome tissue barriers, thus also allowing interaction with single cells. However, real-world plastics sources (rather than commercially available perfectly spherical polystyrene particles) have not yet been used; therefore, further studies applying different plastic materials with significant size and/or shape polydispersity as well as environmentally relevant concentrations need to be conducted to fill the existing knowledge gaps.

3.2. Cellular Uptake Routes and the Intracellular Fate of Nanoplastic Particles. There are several pathways by which nanoparticles can be taken up by cells. ${ }^{154}$ Although passive diffusion through the cell membrane (also referred to as adhesive interaction), channel- or transport-proteinmediated uptake have been described, endocytotic nanoparticle uptake is the major mechanism of cells. A range of endocytotic pathways, including phagocytosis and macropinocytosis, as well as clathrin- and caveolae-mediated endocytosis, have been described. ${ }^{155-157}$ Not all of the studies we present here have been performed with intestine cells; however, our aim is to provide an overview of the current knowledge of polystyrene nanoparticles interaction with human cells.

The first interaction of nanoparticles with cells is the interaction with the outer cell membrane. Rossi et al. investigated the interaction of polystyrene particles with biological membranes by coarse-grained molecular simulations, which revealed that nanosized polystyrene particles can permeate easily into lipid bilayer membranes, alter the membrane structure, and reduce molecular diffusion, thereby affecting possible cell functions. ${ }^{158}$ Fiorentino et al. investigated cellular uptake of $44 \mathrm{~nm}$ polystyrene particles on human colon fibroblasts and bovine oviductal epithelial cells. ${ }^{159}$ By way of uptake inhibition studies, they demonstrated that the polystyrene nanoparticles were internalized mainly via a clathrin-independent uptake mechanism. dos Santos et al. studied the effects of transport inhibitors on the cellular uptake of 40 and $200 \mathrm{~nm}$ carboxylated polystyrene nanoparticles in human cervical HeLa cells, human glial astrocytoma 1321N1, and human lung epithelial A549 cell lines. ${ }^{160}$ The results clearly indicated that in all cases polystyrene nanoparticles entered the cells via active energy-dependent processes. However, since none of the transport inhibitors could fully inhibit polystyrene uptake, the possibility remains that one cell line uses multiple uptake pathways simultaneously.

RBCs are highly specialized cells distinguished by their lack of a cell nucleus and endocytotic uptake mechanism. Studies have been conducted in order to demonstrate cellular uptake of different nanoparticles by RBCs and to better understand the operative uptake mechanism. ${ }^{161,162}$ Rothen-Rutishauser et al. showed uptake of nanosized polystyrene particles (diameter $<200 \mathrm{~nm}$ ) by RBCs. ${ }^{163}$ This result indicated neither an endocytotic nor an actin-based uptake mechanism, therefore suggesting a passive diffusion mechanism for this specific cell type.

However, it is important to mention that the uptake routes are not only size- and surface-chemistry-dependent but also cell-type-specific. The same material can show different cellular uptake pathways: for example, polystyrene nanoparticles with a diameter of $120 \mathrm{~nm}$, which surface had been modified to feature amidine groups, have been shown to be taken up by rat alveolar epithelial monolayers via non-endocytic mechanisms, in contrast to MDCK-II cells, which show particle uptake in an energy-dependent manner. ${ }^{121,164}$ Kuhn et al. showed that a combination of several distinguishable endocytotic uptake mechanisms is involved in the uptake of $40 \mathrm{~nm}$ carboxylated polystyrene nanoparticles by macrophages and epithelial cells. Selected endocytotic pathway inhibitors were applied, and it was revealed in the case of J774A.1 macrophages that macropinocytosis, phagocytosis, and clathrin-mediated endocytosis pathways are involved, whereas for human alveolar epithelial cells (A549), the uptake was dependent on caveolinand clathrin-mediated endocytosis pathways. ${ }^{165}$ Nonvesicular transport through the membrane might allow the nanoplastic particles to interact directly with intracellular molecules or to release their payload, such as POPs, directly into the cytoplasm. This might lead to accumulation of POPs in the cell and potential toxicological effects on the human body. ${ }^{166}$

Endocytosis of plastic particles will follow the intracellular endocytotic pathway involving early and late endosomes followed by fusion with lysosomes. Salvati et al. ${ }^{122}$ demon- 
strated the intracellular lysosomal localization of 40-50 nm polystyrene nanoparticles in A549 cells. These findings are in agreement with other published data, which show accumulation of nanosized polystyrene particles in the lysosome, whereas no lysosomal escape or even particle degradation was observed under acidic conditions. ${ }^{167}$

In another study, the importance of the physicochemical properties of mesoporous silica and polystyrene nanoparticles were compared; the results revealed clear differences in cellular uptake mechanisms using ovarian cancer cells. ${ }^{168}$ It was shown that the two types of nanoparticles never showed an overlap in their endocytotic uptake routes. Mesoporous silica particles entered the cells via caveola-mediated endocytosis and, depending on their size, resided within the lysosome (50 $\mathrm{nm})$ or were relocated in the cytoplasm $(10 \mathrm{~nm})$. Cellular uptake of polystyrene nanoparticle occurred via a caveolaindependent route. Amine-modified $50 \mathrm{~nm}$ polystyrene particles were localized within the lysosome and showed toxicity after $4-8 \mathrm{~h}$ in comparison to $30 \mathrm{~nm}$ carboxyl-modified polystyrene particles, which did not follow the classic acidic endocytotic pathway and were not toxic. It is well-known from the literature that a positive surface charge of nanoparticles often results in increased cytotoxicity and cellular uptake by unspecific binding to negatively charged sugar moieties on the cell surface, whereas negatively charged particles impair endocytosis due to repulsive interactions. ${ }^{169,170} \mathrm{~A}$ variety of cellular uptake routes and intracellular localizations of polystyrene nanoparticles have been observed depending on the physicochemical properties; however, there is a lack of specific quantitative data regarding cellular entry and the fate of nanoplastics.

It is obvious that size matters and plastic nanoparticles interact differently with human cells in comparison with larger ones; however, the uptake is also dependent on the particle charge which might influence the behavior in the cell culture media. Since most of the in vitro studies described here have used polystyrene particles, it is of course difficult to extrapolate the results to other kind of plastic particles and more research with other plastics is highly recommended.

3.3. Adverse Effects of Nanoplastics. Nanosized materials in general have raised concerns regarding possible hazards and risks for the environment and especially for human health. An understanding of possible human exposure is critical to determine health hazards. Adverse effects of nanoparticles in vivo include cytotoxicity, (pro-)inflammation, or production of reactive oxygen species (ROS). ${ }^{171}$ A number of in vitro studies using human cell lines (Table 1 ) have revealed that polymer nanoparticles have the potential to activate the innate immune system, inducing inflammatory responses, or mediating oxidative stress. In in vitro experiments, Brown et al. showed pro-inflammatory responses of polystyrene particles with diameters of 202 and $535 \mathrm{~nm}$ upon exposure to human A549 lung cells, observing an increased IL-8 expression relative to that elucidated by polystyrene nanoparticles with a diameter of $64 \mathrm{~nm} .{ }^{172}$ As seen by Forte et al., unmodified polystyrene nanoparticles with a diameter of $44 \mathrm{~nm}$ induced a strong upregulation of IL-6 and IL-8 genes in experiments using human gastric adenocarcinoma cells, indicating that the induction of pro-inflammatory responses by polystyrene does not necessarily have to be charge-driven (as suggested by many studies) but may instead be a material-based or simple particle occurrence issue. ${ }^{132}$ McCarthy et al. identified the activation of ion channels in human lung cells after exposure to polystyrene nanoparticles. Application of $20 \mathrm{~nm}$ carboxylated polystyrene particles caused continuous short-circuit currents by the activation of basolateral $\mathrm{K}^{+}$channels and the stimulation of $\mathrm{Cl}^{-}$and $\mathrm{HCO}_{3}^{-}$secretion. These findings underline that polystyrene nanoparticles may have the ability to affect the epithelial cell function and physiological processes. ${ }^{173}$ Fuchs et al. investigated the effect of $120 \mathrm{~nm}$ carboxylates and aminomodified polystyrene particles on the polarization of human macrophages into M1 or M2 phenotype. Their observations revealed that the expression of the M1 markers CD86, NOS2, TNF-a, and IL-1b was not affected, while for M2 types both nanoparticles impaired expression of scavenger receptors CD163 and CD200R, and the release of IL-10. The aminomodified particles also inhibited the phagocytosis of Escherichia coli by both, M1 and M2 macrophages, while the carboxylated particles did not affect the phagocytosis of the bacteria by M2, but increased protein mass in M1 and M2, TGF-b1 release by M1, and ATP levels in M2. ${ }^{174}$

A new strategy to develop efficient nanoparticle-based drug delivery systems involves the use of RBCs as a carrier system, which can increase the circulation of nanoparticles in vivo. In this context, Barshtein et al. investigated RBCs with attached polystyrene nanoparticles having diameters of 50, 108, and 243 $\mathrm{nm}$, probing in particular the aggregation of RBCs and their adhesion to endothelial cells. The authors showed that the formation of RBC aggregates increased with decreasing particle size and in parallel a distinctly elevated adhesion to endothelial cells was observed. ${ }^{175}$ In addition, Barbul et al. showed that polystyrene particles with sizes of 27,45 , and $100 \mathrm{~nm}$ adsorbed to RBCs led to shape transformations and reduced cell deformability, with the $27 \mathrm{~nm}$ particles showing the strongest effect. $^{176}$

Furthermore, Xia et al. showed the influence of $30 \mathrm{~nm}$ polystyrene nanoparticles on the endocytotic pathway in macrophages and human cancer cell lines A549, HePG-2, and HCT116. The particles induced the formation of large vesicle-like structures, which blocked the vesicle transport in the endocytic system and the distributions of regular proteins required in cytokinesis, which led to the formation of binucleated cells. ${ }^{177} \mathrm{~A}$ recent study by Inkielewicz-Stepniak et al. investigated the role of mucin in the toxicological impact of polystyrene nanoparticles. Their findings showed that amine-modified $57 \mathrm{~nm}$ sized polystyrene particles have the ability to strongly interact and aggregate mucin and induced apoptosis equally on mucin- and non-mucin-secreting intestinal epithelial cells. ${ }^{178}$ Further studies using cationic polystyrene nanoparticles indicated the increase in ROS production and endoplasmatic reticulum stress caused by misfolded protein aggregation in macrophage (RAW 264.7) and lung epithelial (BEAS-2B) cells, leading to autophagic cell death. ${ }^{179,180} \mathrm{~A}$ further study confirming that polystyrene particles are able to induce ROS production was conducted by Liu et al. In their study they showed that polystyrene particles $500 \mathrm{~nm}$ in size could stimulate ROS generation in human liver cells. ${ }^{181}$

Aside from polystyrene, an in vitro study using unmodified polyethylene particles with sizes ranging from 0.3 to $10 \mu \mathrm{m}$ showed unequivocally that the plastic particles stimulated mice-derived macrophages to produce significant levels of cytokines such as IL- 6 , IL- $1 \beta$, and TNF- $\alpha{ }^{182}$ Furthermore, several studies of human patients have shown that normal usage of implants such as total joint replacements made of polyethylene can lead to the production of wear debris. ${ }^{183-185}$ 


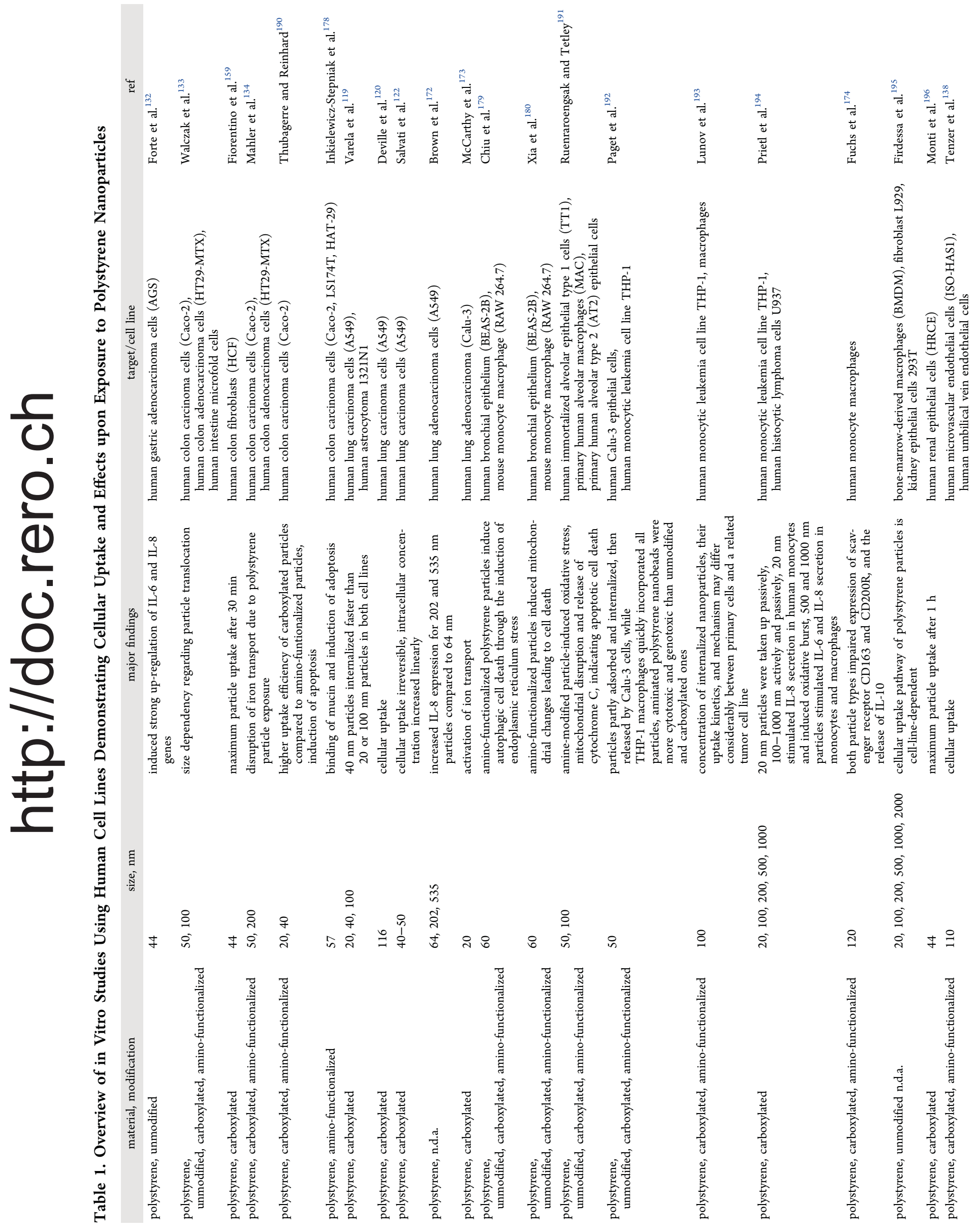


Wear debris polyethylene particles seem to trigger the release of pro-inflammatory factors, such as TNF- $\alpha$, IL- 1 , and proosteoclastic factors such as receptor activator of NF- $\kappa \mathrm{B}$ ligand (RANKL), resulting in periprosthetic bone resorption (osteolysis) and, in the worst case, eventual loss of the implant. ${ }^{186}$ As illustrated by Devane et al., the tissue around ultrahigh molecular weight polyethylene-based prostheses often contains large numbers of small particles with sizes ranging from 0.2 to $10 \mu \mathrm{m}$, and macrophages have been frequently observed, confirming the recruitment of the innate immune system. ${ }^{187}$ Shanbhag et al. analyzed the composition and morphology of wear debris from interfacial membranes of failed total hip replacements. Their findings revealed that most of the particles found were polyethylene and had a mean size of around $530 \mathrm{~nm} .{ }^{188}$ To overcome the observed negative effects, surgeons are now increasingly using metal-on-metal joint replacements.

Furthermore, the production of fluorescein labeled polyethylene terephthalate (PET) nanoparticles was recently shown by Magri et al. ${ }^{189}$ In their study, they present a topdown approach based on laser ablation of polymers to form PET nanoparticles with weak acid groups on their surface, which should mimic real environmental nanopollutants. In vitro studies using human intestinal epithelial cells (Caco-2) showed internalization and biopersistance as well as long-term stability in a simulated lysosomal environment. In addition, cells treated with nano-PET particles did not increase ROS generation over $96 \mathrm{~h}$, and no cytotoxicity was detectable. However, as suggested by the authors, possible long-term effects in cells or tissue cannot be excluded and need to be evaluated further.

In conclusion, it has been shown by in vitro and in vivo data that nanosized plastic particles can induce the activation of cell responses, especially effects on the immune system. However, long-term studies with repeated exposures are absent, as well as thorough material testing, including plastics such as PE, PET, and $\mathrm{PP}$, since most of the current studies are performed with polystyrene particles. Furthermore, it is important to fill the knowledge gap between environmental relevant concentrations and the concentrations found in the organisms/cells to carry out relevant studies on the impact on human health.

\section{DETECTION OF NANOPLASTICS}

The reliable detection of polymer-based nanoparticles in environmental samples or complex biological matrices is highly challenging, due to their small size and the fact that their overall chemical composition is not all too different from that of organic matter. The detection of nanoplastic particles according to their size is not sufficient, as additional chemical characterization is needed for identification of the particles. To the best of our knowledge, only one study has so far been published showing the detection and chemical analysis of nanoplastics in an environmental sample. Ter Halle et al. collected water samples from the North Atlantic Subtropical Gyre, and after ultrafiltration of the water, they used dynamic light scattering to prove the presence of nanoparticles. To evaluate the chemical identity of the particles, they conducted pyrolysis coupled with gas chromatography-mass spectrometry. They estimated that the colloidal fraction signal of seawater could be attributed on average to a mixture of $73 \%$ PVC $( \pm 18 \%), 18 \%$ PET $( \pm 16 \%)$, and $9 \%$ PS $( \pm 10 \%)$. In addition, they observed changes in the pyrolytic signals of polyethylene with decreasing debris size, concluding that this 
could be related to the structural modification of this plastic as a consequence of weathering processes. ${ }^{201}$

A promising possible method for the detection and chemical characterization of nanoplastic particles in complex matrices is hyperspectral imaging technology. Hyperspectral imaging is a recently established technique that quantifies the reflectance intensity of microscopic samples in the UV-vis range (400$1000 \mathrm{~nm}$ ) to generate spectra specific to a material at pixel resolution. ${ }^{202,203}$ Hyperspectral imaging has proven to be suitable for the detection and characterization of microplastic samples from ocean samples as well as from soil. ${ }^{204,205}$ Shan et al. investigated the effects of particle size and color of micoplastics found in soil. The results showed that white PE could be detected with the precisions of $84 \%$ and $77 \%$ for PE particles in size ranges of $1-5 \mathrm{~mm}$ and $0.5-1 \mathrm{~mm}$, respectively, while the precision of black $\mathrm{PE}$ in the same size ranges were found to be $58 \%$ and $76 \%$, respectively. Furthermore, Mattsson et al. demonstrated the use of hyperspectral imaging for the detection of polystyrene nanoparticles with a diameter of $52 \mathrm{~nm}$ within the brain tissue of fish. The brains were homogenized and polystyrene was spectrally mapped and identified in the exposed brain images using the Spectral Angle Mapper algorithm. ${ }^{90}$

Methods used to characterize nanoparticles in general such as UV-vis spectrometry, electron microscopy, field flow fractionation (FFF), or dynamic light scattering (DLS) techniques have also been suggested to be suitable for nanoplastics. However, these methods need to be combined to achieve the chemical confirmation of the identity of the material, as this is often lacking as seen by Correia et al. ${ }^{206}$ New approaches might involve the introduction of nano-FTIR absorption spectroscopy and Raman spectroscopy as well as combined atomic force microscopy and infrared spectroscopy (AFM-IR), which all show the capabilities in the area of nanoscale chemical characterization. ${ }^{207-209}$

In conclusion, there is still a lack of reliable methods to detect nanoplastic particles in combination with reliable chemical characterization in environmental samples and/or complex biological matrices.

\section{CONCLUSIONS AND FUTURE PERSPECTIVES}

Polymers represent one of the most important materials families of the 21 st century, as they are used practically everywhere and strongly influence our daily lives in many different ways. At the same time, these materials as a whole are also one of the largest sources of environmental pollution that mankind is exposed to. Recent studies have presented evidence that the process of plastic degradation also results in the formation of nanoplastic with physicochemical characteristics different from the corresponding bulk materials. An increasing body of knowledge has shown that nanoplastics have adverse effects on aquatic species, but in contrast to microplastics, nanoplastics can overcome the intestine tissue in aquatic systems and therefore possibly end up in the human food chain. Thus, it appears important to accelerate the investigation of the presence and fate of nanoplastics in the (aquatic) environment. In addition to studies addressing the effects of nanoplastics on aquatic organisms, exposure risks for humans via the food chain should be explored in more detail as in vitro studies using human cell lines showed evidence that polystyrene nanoparticles are taken up and induce oxidative stress or pro-inflammatory responses. Furthermore, information on the long-term fate of ingested nanoplastics in aquatic organisms and humans is limited, and several important questions for future studies remain such as the following: What is the concentration of nanoplastics in the water? Can this concentration impact the aquatic system and, thus the food chain, resulting in potential hazardous effects for humans? Can we confirm the occurrence of nanoplastic in the human food chain to determine the potential exposure to humans? Given these unsolved questions, new technological approaches and methods are needed for the detection of nanoplastic particles in the environment and in organisms.

In addition, it is not known to what extent nanoplastic can be further degraded after ingestion, for example under the acidic conditions found in the gut or inside the cells in the digestive organelles, i.e., the lysosomes. It is also unclear whether nanoplastic can overcome the gut-intestine epithelial barrier or if they are restricted to the gut lumen. Another interesting question is to what extent the ingestion of nanoplastic can promote the uptake of chemical hitchhikers and the possible leaching of chemicals from the plastic material that could cause harm to the human body. In addition, plastic particles appear in numerous types, shapes, and sizes, with or without associated chemicals. Inconsistent use of units, exposure media, and habitats makes it even more difficult to combine exposure and effect data in a significant characterization of the risks. This turns the development of a rational risk assessment framework for plastic into a very challenging task. ${ }^{68}$ Unfortunately, it stands to reason that many aspects in the context of environmental polymer nanoparticles cannot be generalized. There is therefore a need to establish data for the different plastic materials found in the environment. While the most commercially most relevant polymers are polyolefins (notably different types of polyethylenes and polypropylene), polyesters, and polyurethanes, most of the studies conducted with polymer nanoparticles were carried out with polystyrene, as this material is commercially available and inexpensive and can also be easily synthesized and processed into nanoparticles. Therefore, we propose that focus should be placed on comprehensive studies using diverse plastic materials at relevant concentrations, as well as modeling chronic exposure, for a more realistic hazard and risk assessment. Future research should also move toward the terrestrial environment, about which even less is known. Studies involving terrestrial, but also freshwater eco-systems will be very supportive for the overall understanding of the micro- and nanoplastic pollution in the environment and its possible impact on human health. ${ }^{37}$

\section{AUTHOR INFORMATION}

\section{Corresponding Author}

*Phone: +41 26300 9502; E-mail: barbara.rothen@unifr.ch.

\section{ORCID}

Roman Lehner: 0000-0002-0478-5445

Christoph Weder: 0000-0001-7183-1790

Alke Petri-Fink: 0000-0003-3952-7849

\section{Notes}

The authors declare no competing financial interest.

\section{ACKNOWLEDGMENTS}

This work was supported by the Adolphe Merkle Foundation and the Grant No. 310030_159847/1 to B.R.-R. We thank Dr. Miguel Spuch for the illustrational work of the TOC art graphic and Figure 3. 


\section{REFERENCES}

(1) Lodge, T. P. Celebrating 50 Years of Macromolecules. Macromolecules 2017, 50 (24), 9525-9527.

(2) Ebewele, R. O. Polymer Science and Technology; Taylor \& Francis, 2000; pp 1-544.

(3) Fried, J. R. Polymer Science and Technology, 3rd ed.; Pearson Education, 2014; pp 1-76.

(4) Schneiderman, D. K.; Hillmyer, M. A. 50th Anniversary Perspective: There Is a Great Future in Sustainable Polymers. Macromolecules 2017, 50 (10), 3733-3749.

(5) Andrady, A. L.; Neal, M. A. Applications and societal benefits of plastics. Philos. Trans. R. Soc., B 2009, 364 (1526), 1977-1984.

(6) Thompson, R. C.; Swan, S. H.; Moore, C. J.; vom Saal, F. S. Our plastic age. Philos. Trans. R. Soc., B 2009, 364 (1526), 1973-1976.

(7) Andrady, A. L. Plastics and Environmental Sustainability; John Wiley \& Sons: Hoboken, NJ, USA, 2015; DOI: 10.1002/ 9781119009405.

(8) Hahladakis, J. N.; Velis, C. A.; Weber, R.; Iacovidou, E.; Purnell, P. An overview of chemical additives present in plastics: Migration, release, fate and environmental impact during their use, disposal and recycling. J. Hazard. Mater. 2018, 344, 179-199.

(9) Oehlmann, J.; Schulte-Oehlmann, U.; Kloas, W.; Jagnytsch, O.; Lutz, I.; Kusk, K. O.; Wollenberger, L.; Santos, E. M.; Paull, G. C.; Van Look, K. J. W.; Tyler, C. R. A critical analysis of the biological impacts of plasticizers on wildlife. Philos. Trans. R. Soc., B 2009, 364 (1526), 2047-2062.

(10) Plastics-the Facts 2017; PlasticEurope; PlasticsEurope: Brussels, Belgium, 2018; pp 1-44.

(11) Plastics-the Facts 2016; PlasticsEurope: Brussels, Belgium, 2016; pp 1-38.

(12) Luengo, C.; Allen, N. S.; Edge, M.; Wilkinson, A.; Parellada, M. D.; Barrio, J. A.; Santa, V. R. Photo-oxidative degradation mechanisms in styrene-ethylene-butadiene-styrene (SEBS) triblock copolymer. Polym. Degrad. Stab. 2006, 91 (4), 947-956.

(13) Eubeler, J. P.; Bernhard, M.; Knepper, T. P. Environmental biodegradation of synthetic polymers II. Biodegradation of different polymer groups. TrAC, Trends Anal. Chem. 2010, 29 (1), 84-100.

(14) Yousif, E.; Haddad, R. Photodegradation and photostabilization of polymers, especially polystyrene: review. SpringerPlus 2013, 2 (1), 398.

(15) Cao, H.; Yuan, J. P.; Zhang, R.; Huang, C. M.; He, Y.; Sandreczki, T. C.; Jean, Y. C.; Nielsen, B.; Suzuki, R.; Ohdaira, T. Degradation of Polymer Coating Systems Studied by Positron Annihilation Spectroscopy. 3. Wavelength Dependence of UV Irradiation Effect. Macromolecules 1999, 32 (18), 5925-5933.

(16) Maniar, M. L.; Kalonia, D. S.; Simonelli, A. P. Determination of specific rate constants of specific oligomers during polyester hydrolysis. J. Pharm. Sci. 1991, 80 (8), 778-782.

(17) Merdas, I.; Thominette, F.; Verdu, J. Hydrolytic ageing of polyamide 11 -effect of carbon dioxide on polyamide 11 hydrolysis. Polym. Degrad. Stab. 2003, 79 (3), 419-425.

(18) Da Costa, J. P.; Nunes, A. R.; Santos, P. S. M.; Girão, A. V.; Duarte, A. C.; Rocha-Santos, T. Degradation of polyethylene microplastics in seawater: Insights into the environmental degradation of polymers. J. Environ. Sci. Health, Part A: Toxic/Hazard. Subst. Environ. Eng. 2018, 53 (9), 866-875.

(19) Lambert, S.; Wagner, M. Characterisation of nanoplastics during the degradation of polystyrene. Chemosphere 2016, 145, 265268.

(20) Barnes, D. K. A.; Galgani, F.; Thompson, R. C.; Barlaz, M. Accumulation and fragmentation of plastic debris in global environments. Philos. Trans. R. Soc., B 2009, 364 (1526), 1985-1998.

(21) Jambeck, J. R.; Geyer, R.; Wilcox, C.; Siegler, T. R.; Perryman, M.; Andrady, A.; Narayan, R.; Law, K. L. Plastic waste inputs from land into the ocean. Science 2015, 347 (6223), 768-771.

(22) Eriksen, M.; Lebreton, L. C. M.; Carson, H. S.; Thiel, M.; Moore, C. J.; Borerro, J. C.; Galgani, F.; Ryan, P. G.; Reisser, J. Plastic Pollution in the World's Oceans: More than 5 Trillion Plastic Pieces
Weighing over 250,000 Tons Afloat at Sea. PLoS One 2014, 9 (12), No. e111913.

(23) van Sebille, E.; Wilcox, C.; Lebreton, L.; Maximenko, N.; Hardesty, B. D.; van Franeker, J. A.; Eriksen, M.; Siegel, D.; Galgani, F.; Law, K. L. A global inventory of small floating plastic debris. Environ. Res. Lett. 2015, 10 (12), 124006.

(24) Lebreton, L.; Slat, B.; Ferrari, F.; Sainte-Rose, B.; Aitken, J.; Marthouse, R.; Hajbane, S.; Cunsolo, S.; Schwarz, A.; Levivier, A.; Noble, K.; Debeljak, P.; Maral, H.; Schoeneich-Argent, R.; Brambini, R.; Reisser, J.; et al. Evidence that the Great Pacific Garbage Patch is rapidly accumulating plastic. Sci. Rep. 2018, 8 (1), 4666.

(25) Galgani, F.; Burgeot, T.; Bocquéné, G.; Vincent, F.; Leauté, J. P.; Labastie, J.; Forest, A.; Guichet, R. Distribution and abundance of debris on the continental shelf of the Bay of Biscay and in Seine Bay. Mar. Pollut. Bull. 1995, 30 (1), 58-62.

(26) Galgani, F.; Souplet, A.; Cadiou, Y. Accumulation of debris on the deep sea floor off the French Mediterranean coast. Mar. Ecol.: Prog. Ser. 1996, 142, 225-234.

(27) Chiba, S.; Saito, H.; Fletcher, R.; Yogi, T.; Kayo, M.; Miyagi, S.; Ogido, M.; Fujikura, K. Human footprint in the abyss: 30 year records of deep-sea plastic debris. Marine Policy 2018, 96, 204-212.

(28) Naidu, S. A.; Ranga Rao, V.; Ramu, K. Microplastics in the benthic invertebrates from the coastal waters of Kochi, Southeastern Arabian Sea. Environ. Geochem. Health 2018, 40 (4), 1377-1383.

(29) Fang, C.; Zheng, R.; Zhang, Y.; Hong, F.; Mu, J.; Chen, M.; Song, P.; Lin, L.; Lin, H.; Le, F.; et al. Microplastic contamination in benthic organisms from the Arctic and sub-Arctic regions. Chemosphere 2018, 209, 298-306.

(30) Woodall, L. C.; Sanchez-Vidal, A.; Canals, M.; Paterson, G. L. J.; Coppock, R.; Sleight, V.; Calafat, A.; Rogers, A. D.; Narayanaswamy, B. E.; Thompson, R. C. The deep sea is a major sink for microplastic debris. R. Soc. Open Sci. 2014, 1 (4), 140317.

(31) Taylor, M. L.; Gwinnett, C.; Robinson, L. F.; Woodall, L. C. Plastic microfibre ingestion by deep-sea organisms. Sci. Rep. 2016, 6 (1), 33997.

(32) Martin, J.; Lusher, A.; Thompson, R. C.; Morley, A. The Deposition and Accumulation of Microplastics in Marine Sediments and Bottom Water from the Irish Continental Shelf. Sci. Rep. 2017, 7 (1), 10772.

(33) Rummel, C. D.; Jahnke, A.; Gorokhova, E.; Kühnel, D.; Schmitt-Jansen, M. Impacts of Biofilm Formation on the Fate and Potential Effects of Microplastic in the Aquatic Environment. Environ. Sci. Technol. Lett. 2017, 4 (7), 258-267.

(34) Chubarenko, I.; Bagaev, A.; Zobkov, M.; Esiukova, E. On some physical and dynamical properties of microplastic particles in marine environment. Mar. Pollut. Bull. 2016, 108 (1-2), 105-112.

(35) Hintersteiner, I.; Himmelsbach, M.; Buchberger, W. W. Characterization and quantitation of polyolefin microplastics in personal-care products using high-temperature gel-permeation chromatography. Anal. Bioanal. Chem. 2015, 407 (4), 1253-1259.

(36) de Souza Machado, A. A.; Kloas, W.; Zarfl, C.; Hempel, S.; Rillig, M. C. Microplastics as an emerging threat to terrestrial ecosystems. Glob Chang Biol. 2018, 24 (4), 1405-1416.

(37) Rochman, C. M. Microplastics research-from sink to source. Science 2018, 360 (6384), 28-29.

(38) Awet, T. T.; Kohl, Y.; Meier, F.; Straskraba, S.; Grün, A. L.; Ruf, T.; Jost, C.; Drexel, R.; Tunc, E.; Emmerling, C. Effects of polystyrene nanoparticles on the microbiota and functional diversity of enzymes in soil. Environ. Sci. Eur. 2018, 30 (1), 11.

(39) da Costa, J. P.; Santos, P. S. M.; Duarte, A. C.; Rocha-Santos, T. (Nano)plastics in the environment - Sources, fates and effects. Sci. Total Environ. 2016, 566-567, 15-26.

(40) Carpenter, E. J.; Smith, K. L. Plastics on the Sargasso sea surface. Science 1972, 175 (4027), 1240-1241.

(41) Colton, J. B., Jr.; Knapp, F. D.; Burns, B. R. Plastic particles in surface waters of the Northwestern Atlantic. Science 1974, 185 (4150), 491-497. 
(42) Gigault, J.; Pedrono, B.; Maxit, B.; Ter Halle, A. Marine plastic litter: the unanalyzed nano-fraction. Environ. Sci.: Nano 2016, 3 (2), $346-350$.

(43) Koelmans, A. A.; Besseling, E.; Shim, W. J. Nanoplastics in the Aquatic Environment. Critical Review. Marine Anthropogenic Litter; Springer: Cham, Switzerland, 2015; pp 325-340, DOI: 10.1007/ 978-3-319-16510-3_12.

(44) Murty, B. S.; Shankar, P.; Raj, B.; Rath, B. B.; Murday, J. Unique Properties of Nanomaterials 2013, 29-65.

(45) Zhang, X.-Q.; Xu, X.; Bertrand, N.; Pridgen, E.; Swami, A.; Farokhzad, O. C. Interactions of nanomaterials and biological systems: Implications to personalized nanomedicine. Adv. Drug Delivery Rev. 2012, 64 (13), 1363-1384.

(46) Maurer-Jones, M. A.; Gunsolus, I. L.; Murphy, C. J.; Haynes, C. L. Toxicity of Engineered Nanoparticles in the Environment. Anal. Chem. 2013, 85 (6), 3036-3049.

(47) Velzeboer, I.; Kwadijk, C. J. A. F.; Koelmans, A. A. Strong Sorption of PCBs to Nanoplastics, Microplastics, Carbon Nanotubes, and Fullerenes. Environ. Sci. Technol. 2014, 48 (9), 4869-4876.

(48) Engler, R. E. The complex interaction between marine debris and toxic chemicals in the ocean. Environ. Sci. Technol. 2012, 46 (22), $12302-12315$

(49) Jiang, R.; Lin, W.; Wu, J.; Xiong, Y.; Zhu, F.; Bao, L.-J.; You, J.; Ouyang, G.; Zeng, E. Y. Quantifying nanoplastic-bound chemicals accumulated in Daphnia magnawith a passive dosing method. Environ. Sci.: Nano 2018, 5 (3), 776-781.

(50) Wright, S. L.; Kelly, F. J. Plastic and Human Health: A Micro Issue? Environ. Sci. Technol. 2017, 51 (12), 6634-6647.

(51) Revel, M.; Châtel, A.; Mouneyrac, C. Micro(nano)plastics: A threat to human health? Current Opinion in Environmental Science \& Health 2018, 1, 17-23.

(52) Human Health Impacts of Microplastics and Nanoplastics; New Jersey Department of Environmental Protection (NJDEP) Science Advisory Board, 2016; pp 1-23.

(53) Alessi, E. Out of the plastic trap: Saving the Mediterranean from plastic pollution. WWF Mediterranean Marine Initiative; World Wide Fund for Nature (WWF), 2018; pp 1-28.

(54) Villarrubia-Gómez, P.; Cornell, S. E.; Fabres, J. Marine plastic pollution as a planetary boundary threat - The drifting piece in the sustainability puzzle. Marine Policy 2018, 96, 213-220.

(55) Hopewell, J.; Dvorak, R.; Kosior, E. Plastics recycling: challenges and opportunities. Philos. Trans. R. Soc., B 2009, 364 (1526), 2115-2126.

(56) Swift, G. Degradable Polymers and Plastics in Landfill Sites; John Wiley \& Sons: Hoboken, NJ, USA, 2002; Vol. 179, pp 1-13, DOI: $10.1002 / 0471440264 . p s t 457 . p u b 2$.

(57) Derraik, J. G. B. The pollution of the marine environment by plastic debris: a review. Mar. Pollut. Bull. 2002, 44 (9), 842-852.

(58) Teuten, E. L.; Rowland, S. J.; Galloway, T. S.; Thompson, R. C. Potential for Plastics to Transport Hydrophobic Contaminants. Environ. Sci. Technol. 2007, 41 (22), 7759-7764.

(59) Cole, M.; Lindeque, P.; Fileman, E.; Halsband, C.; Goodhead, R.; Moger, J.; Galloway, T. S. Microplastic ingestion by zooplankton. Environ. Sci. Technol. 2013, 47 (12), 6646-6655.

(60) Li, J.; Yang, D.; Li, L.; Jabeen, K.; Shi, H. Microplastics in commercial bivalves from China. Environ. Pollut. 2015, 207, 190-195. (61) Bråte, I. L. N.; Eidsvoll, D. P.; Steindal, C. C.; Thomas, K. V. Plastic ingestion by Atlantic cod (Gadus morhua) from the Norwegian coast. Mar. Pollut. Bull. 2016, 112 (1-2), 105-110.

(62) Browne, M. A.; Crump, P.; Niven, S. J.; Teuten, E.; Tonkin, A.; Galloway, T.; Thompson, R. Accumulation of microplastic on shorelines woldwide: sources and sinks. Environ. Sci. Technol. 2011, 45 (21), 9175-9179.

(63) Fendall, L. S.; Sewell, M. A. Contributing to marine pollution by washing your face: Microplastics in facial cleansers. Mar. Pollut. Bull. 2009, 58 (8), 1225-1228.

(64) Obbard, R. W.; Sadri, S.; Wong, Y. Q.; Khitun, A. A.; Baker, I.; Thompson, R. C. Global warming releases microplastic legacy frozen in Arctic Sea ice. Earth's Future 2014, 2 (6), 315-320.
(65) Mattsson, K.; Hansson, L. A.; Cedervall, T. Nano-plastics in the aquatic environment. Environ. Sci.: Processes Impacts 2015, 17 (10), $1712-1721$.

(66) Mattsson, K.; Jocic, S.; Doverbratt, I.; Hansson, L.-A. Nanoplastics in the Aquatic Environment. Microplastic Contamination in Aquatic Environments: An Emerging Matter of Environmental Urgency; Elsevier Inc., 2018; Chapter 13, pp 379-399, DOI: 10.1016/B978-0-12-813747-5.00013-8.

(67) Hernandez, L. M.; Yousefi, N.; Tufenkji, N. Are There Nanoplastics in Your Personal Care Products? Environ. Sci. Technol. Lett. 2017, 4 (7), 280-285.

(68) Koelmans, A. A.; Besseling, E.; Foekema, E.; Kooi, M.; Mintenig, S.; Ossendorp, B. C.; Redondo-Hasselerharm, P. E.; Verschoor, A.; van Wezel, A. P.; Scheffer, M. Risks of Plastic Debris: Unravelling Fact, Opinion, Perception, and Belief. Environ. Sci. Technol. 2017, 51 (20), 11513-11519.

(69) Gigault, J.; Halle, A. T.; Baudrimont, M.; Pascal, P.-Y.; Gauffre, F.; Phi, T.-L.; El Hadri, H.; Grassl, B.; Reynaud, S. Current opinion: What is a nanoplastic? Environ. Pollut. 2018, 235, 1030-1034.

(70) Definition of a Nanomaterial; European Commission, 2018; http://ec.europa.eu/environment/chemicals/nanotech/faq/ definition_en.htm.

(71) Bouwmeester, H.; Hollman, P. C. H.; Peters, R. J. B. Potential Health Impact of Environmentally Released Micro- and Nanoplastics in the Human Food Production Chain: Experiences from Nanotoxicology. Environ. Sci. Technol. 2015, 49 (15), 8932-8947.

(72) von Moos, N.; Burkhardt-Holm, P.; Köhler, A. Uptake and effects of microplastics on cells and tissue of the blue mussel Mytilus edulis L. after an experimental exposure. Environ. Sci. Technol. 2012, 46 (20), 11327-11335.

(73) Wright, S. L.; Thompson, R. C.; Galloway, T. S. The physical impacts of microplastics on marine organisms: a review. Environ. Pollut. 2013, 178, 483-492.

(74) Nobre, C. R.; Santana, M. F. M.; Maluf, A.; Cortez, F. S.; Cesar, A.; Pereira, C. D. S.; Turra, A. Assessment of microplastic toxicity to embryonic development of the sea urchin Lytechinus variegatus (Echinodermata: Echinoidea). Mar. Pollut. Bull. 2015, 92 (1-2), 99104.

(75) Booth, A. M.; Hansen, B. H.; Frenzel, M.; Johnsen, H.; Altin, D. Uptake and toxicity of methylmethacrylate-based nanoplastic particles in aquatic organisms. Environ. Toxicol. Chem. 2016, 35 (7), 16411649.

(76) Ward, J. E.; Kach, D. J. Marine aggregates facilitate ingestion of nanoparticles by suspension-feeding bivalves. Mar. Environ. Res. 2009, 68 (3), 137-142.

(77) Bhattacharya, P.; Lin, S.; Turner, J. P.; Ke, P. C. Physical Adsorption of Charged Plastic Nanoparticles Affects Algal Photosynthesis. J. Phys. Chem. C 2010, 114 (39), 16556-16561.

(78) Besseling, E.; Wang, B.; Lürling, M.; Koelmans, A. A. Nanoplastic affects growth of S. obliquus and reproduction of D. magna. Environ. Sci. Technol. 2014, 48 (20), 12336-12343.

(79) Canesi, L.; Ciacci, C.; Bergami, E.; Monopoli, M. P.; Dawson, K. A.; Papa, S.; Canonico, B.; Corsi, I. Evidence for immunomodulation and apoptotic processes induced by cationic polystyrene nanoparticles in the hemocytes of the marine bivalve Mytilus. Mar. Environ. Res. 2015, 111, 34-40.

(80) Sun, X.; Chen, B.; Li, Q.; Liu, N.; Xia, B.; Zhu, L.; Qu, K. Toxicities of polystyrene nano- and microplastics toward marine bacterium Halomonas alkaliphila. Sci. Total Environ. 2018, 642, $1378-1385$.

(81) Tallec, K.; Huvet, A.; Di Poi, C.; González-Fernández, C.; Lambert, C.; Petton, B.; Le Goïc, N.; Berchel, M.; Soudant, P.; PaulPont, I. Nanoplastics impaired oyster free living stages, gametes and embryos. Environ. Pollut. 2018, 242 (Pt B), 1226-1235.

(82) Brandts, I.; Teles, M.; Gonçalves, A. P.; Barreto, A.; FrancoMartinez, L.; Tvarijonaviciute, A.; Martins, M. A.; Soares, A. M. V. M.; Tort, L.; Oliveira, M. Effects of nanoplastics on Mytilus galloprovincialis after individual and combined exposure with carbamazepine. Sci. Total Environ. 2018, 643, 775-784. 
(83) Della Torre, C.; Bergami, E.; Salvati, A.; Faleri, C.; Cirino, P.; Dawson, K. A.; Corsi, I. Accumulation and Embryotoxicity of Polystyrene Nanoparticles at Early Stage of Development of Sea Urchin Embryos Paracentrotus lividus. Environ. Sci. Technol. 2014, 48 (20), 12302-12311.

(84) Liu, Z.; Cai, M.; Yu, P.; Chen, M.; Wu, D.; Zhang, M.; Zhao, Y. Age-dependent survival, stress defense, and AMPK in Daphnia pulex after short-term exposure to a polystyrene nanoplastic. Aquat. Toxicol. 2018, 204, 1-8.

(85) Greven, A. C.; Merk, T.; Karagöz, F.; Mohr, K.; Klapper, M.; Jovanović, B.; Palić, D. Polycarbonate and polystyrene nanoplastic particles act as stressors to the innate immune system of fathead minnow (Pimephales promelas). Environ. Toxicol. Chem. 2016, 35 (12), 3093-3100.

(86) Lu, Y.; Zhang, Y.; Deng, Y.; Jiang, W.; Zhao, Y.; Geng, J.; Ding, L.; Ren, H. Uptake and Accumulation of Polystyrene Microplastics in Zebrafish (Danio rerio) and Toxic Effects in Liver. Environ. Sci. Technol. 2016, 50 (7), 4054-4060.

(87) Marques-Santos, L. F.; Grassi, G.; Bergami, E.; Faleri, C.; Balbi, T.; Salis, A.; Damonte, G.; Canesi, L.; Corsi, I. Cationic polystyrene nanoparticle and the sea urchin immune system: biocorona formation, cell toxicity, and multixenobiotic resistance phenotype. Nanotoxicology 2018, 12 (8), 847-867.

(88) Wegner, A.; Besseling, E.; Foekema, E. M.; Kamermans, P.; Koelmans, A. A. Effects of nanopolystyrene on the feeding behavior of the blue mussel (Mytilus edulis L.). Environ. Toxicol. Chem. 2012, 31 (11), 2490-2497.

(89) Pitt, J. A.; Kozal, J. S.; Jayasundara, N.; Massarsky, A.; Trevisan, R.; Geitner, N.; Wiesner, M.; Levin, E. D.; Di Giulio, R. T. Uptake, tissue distribution, and toxicity of polystyrene nanoparticles in developing zebrafish (Danio rerio). Aquat. Toxicol. 2018, 194, 185194.

(90) Mattsson, K.; Johnson, e.; Malmendal, A.; Linse, S.; Hansson, L.-A.; Cedervall, T. Brain damage and behavioural disorders in fish induced by plastic nanoparticles delivered through the food chain. Sci. Rep. 2017, 7 (1), 11452.

(91) Park, M. R.; Han, K. O.; Han, I. K.; Cho, M.-H.; Nah, J. W.; Choi, Y. J.; Cho, C. S. Degradable polyethylenimine-poly(ethylene glycol) copolymers as novel gene carriers. J. Controlled Release 2005, 105 (3), 367-380.

(92) Hüffer, T.; Praetorius, A.; Wagner, S.; von der Kammer, F.; Hofmann, T. Microplastic Exposure Assessment in Aquatic Environments: Learning from Similarities and Differences to Engineered Nanoparticles. Environ. Sci. Technol. 2017, 51 (5), 2499-2507.

(93) Oriekhova, O.; Stoll, S. Heteroaggregation of nanoplastic particles in the presence of inorganic colloids and natural organic matter. Environ. Sci.: Nano 2018, 5 (3), 792-799.

(94) Petosa, A. R.; Jaisi, D. P.; Quevedo, I. R.; Elimelech, M.; Tufenkji, N. Aggregation and deposition of engineered nanomaterials in aquatic environments: role of physicochemical interactions. Environ. Sci. Technol. 2010, 44 (17), 6532-6549.

(95) Galloway, T. S. Micro- and Nano-plastics and Human Health. Marine Anthropogenic Litter; Springer: Cham, Switzerland, 2015; pp 343-366, DOI: 10.1007/978-3-319-16510-3 13.

(96) Lenz, R.; Enders, K.; Nielsen, T. G. Microplastic exposure studies should be environmentally realistic. Proc. Natl. Acad. Sci. U. S. A. 2016, 113 (29), E4121-E4122.

(97) Prata, J. C. Airborne microplastics: Consequences to human health? Environ. Pollut. 2018, 234, 115-126.

(98) Mattsson, K.; Ekvall, M. T.; Hansson, L.-A.; Linse, S.; Malmendal, A.; Cedervall, T. Altered Behavior, Physiology, and Metabolism in Fish Exposed to Polystyrene Nanoparticles. Environ. Sci. Technol. 2015, 49 (1), 553-561.

(99) Cedervall, T.; Hansson, L.-A.; Lard, M.; Frohm, B.; Linse, S. Food chain transport of nanoparticles affects behaviour and fat metabolism in fish. PLoS One 2012, 7 (2), No. e32254.

(100) Neves, D.; Sobral, P.; Ferreira, J. L.; Pereira, T. Ingestion of microplastics by commercial fish off the Portuguese coast. Mar. Pollut. Bull. 2015, 101 (1), 119-126.
(101) Devriese, L. I.; van der Meulen, M. D.; Maes, T.; Bekaert, K.; Paul-Pont, I.; Frère, L.; Robbens, J.; Vethaak, A. D. Microplastic contamination in brown shrimp (Crangon crangon, Linnaeus 1758) from coastal waters of the Southern North Sea and Channel area. Mar. Pollut. Bull. 2015, 98 (1-2), 179-187.

(102) Yang, D.; Shi, H.; Li, L.; Li, J.; Jabeen, K.; Kolandhasamy, P. Microplastic Pollution in Table Salts from China. Environ. Sci. Technol. 2015, 49 (22), 13622-13627.

(103) Liebezeit, G.; Liebezeit, E. Non-pollen particulates in honey and sugar. Food Addit. Contam., Part A 2013, 30 (12), 2136-2140.

(104) Liebezeit, G.; Liebezeit, E. Synthetic particles as contaminants in German beers. Food Addit. Contam., Part A 2014, 31 (9), 15741578.

(105) Kosuth, M.; Mason, S. A.; Wattenberg, E. V. Anthropogenic contamination of tap water, beer, and sea salt. PLoS One 2018, 13 (4), No. e0194970.

(106) Mason, S. A.; Welch, V. G.; Neratko, J. Synthetic Polymer Contamination in Bottled Water. Front. Chem. 2018, 6, 10377.

(107) Mintenig, S. M.; Löder, M. G. J.; Primpke, S.; Gerdts, G. Low numbers of microplastics detected in drinking water from ground water sources. Sci. Total Environ. 2019, 648, 631-635.

(108) Lithner, D.; Larsson, Å.; Dave, G. Environmental and health hazard ranking and assessment of plastic polymers based on chemical composition. Sci. Total Environ. 2011, 409 (18), 3309-3324.

(109) Lang, I. A.; Galloway, T. S.; Scarlett, A.; Henley, W. E.; Depledge, M.; Wallace, R. B.; Melzer, D. Association of Urinary Bisphenol A Concentration With Medical Disorders and Laboratory Abnormalities in Adults. JAMA 2008, 300 (11), 1303-1310.

(110) Ehrlich, S.; Williams, P. L.; Missmer, S. A.; Flaws, J. A.; Ye, X.; Calafat, A. M.; Petrozza, J. C.; Wright, D.; Hauser, R. Urinary bisphenol A concentrations and early reproductive health outcomes among women undergoing IVF. Hum. Reprod. 2012, 27 (12), 35833592.

(111) Miao, M.; Yuan, W.; Zhu, G.; He, X.; Li, D.-K. In utero exposure to bisphenol-A and its effect on birth weight of offspring. Reprod. Toxicol. 2011, 32 (1), 64-68.

(112) Hengstler, J. G.; Foth, H.; Gebel, T.; Kramer, P. J.; Lilienblum, W.; Schweinfurth, H.; Völkel, W.; Wollin, K. M.; Gundert-Remy, U. Critical evaluation of key evidence on the human health hazards of exposure to bisphenol A. Crit. Rev. Toxicol. 2011, 41 (4), 263-291.

(113) Gehr, P.; Bachofen, M.; Weibel, E. R. The normal human lung: ultrastructure and morphometric estimation of diffusion capacity. Respir. Physiol. 1978, 32 (2), 121-140.

(114) Borm, P. J. A.; Kreyling, W. Toxicological Hazards of Inhaled Nanoparticles;Potential Implications for Drug Delivery. J. Nanosci. Nanotechnol. 2004, 4 (5), 521-531.

(115) Rothen-Rutishauser, B.; Blank, F.; Mühlfeld, C.; Gehr, P. In vitro models of the human epithelial airway barrier to study the toxic potential of particulate matter. Expert Opin. Drug Metab. Toxicol. 2008, 4 (8), 1075-1089.

(116) Holm, M.; Dahlman-Höglund, A.; Torén, K. Respiratory health effects and exposure to superabsorbent polymer and paper dust an epidemiological study. BMC Public Health 2011, 11 (1), 557.

(117) Mastrangelo, G.; Fedeli, U.; Fadda, E.; Milan, G.; Turato, A.; Pavanello, S. Lung cancer risk in workers exposed to poly(vinyl chloride) dust: a nested case-referent study. Occup. Environ. Med. 2003, 60 (6), 423-428.

(118) Richards, R. J.; Cobb, L. M.; Hardy, C. J.; Rose, F. A.; Tetley, T. D. Effects in the rat of inhaling PVC dust at the nuisance dust level (10 mg/m3). Arch. Environ. Health 1981, 36 (1), 14-19.

(119) Varela, J. A.; Bexiga, M. G.; Åberg, C.; Simpson, J. C.; Dawson, K. A. Quantifying size-dependent interactions between fluorescently labeled polystyrene nanoparticles and mammalian cells. J. Nanobiotechnol. 2012, 10 (1), 39.

(120) Deville, S.; Penjweini, R.; Smisdom, N.; Notelaers, K.; Nelissen, I.; Hooyberghs, J.; Ameloot, M. Intracellular dynamics and fate of polystyrene nanoparticles in A549 Lung epithelial cells monitored by image (cross-) correlation spectroscopy and single 
particle tracking. Biochim. Biophys. Acta, Mol. Cell Res. 2015, 1853 (10), 2411-2419.

(121) Yacobi, N. R.; DeMaio, L.; Xie, J.; Hamm-Alvarez, S. F.; Borok, Z.; Kim, K.-J.; Crandall, E. D. Polystyrene nanoparticle trafficking across alveolar epithelium. Nanomedicine 2008, 4 (2), 139145 .

(122) Salvati, A.; Åberg, C.; dos Santos, T.; Varela, J.; Pinto, P.; Lynch, I.; Dawson, K. A. Experimental and theoretical comparison of intracellular import of polymeric nanoparticles and small molecules: toward models of uptake kinetics. Nanomedicine 2011, 7 (6), 818826.

(123) Dris, R.; Gasperi, J.; Saad, M.; Mirande, C.; Tassin, B. Synthetic fibers in atmospheric fallout: A source of microplastics in the environment? Mar. Pollut. Bull. 2016, 104 (1-2), 290-293.

(124) Dris, R.; Gasperi, J.; Mirande, C.; Mandin, C.; Guerrouache, M.; Langlois, V.; Tassin, B. A first overview of textile fibers, including microplastics, in indoor and outdoor environments. Environ. Pollut. 2017, 221, 453-458.

(125) Occupational Safety and Health Administration, U.S. Department of Labor. www.osha.gov.

(126) Gasperi, J.; Wright, S. L.; Dris, R.; Collard, F.; Mandin, C.; Guerrouache, M.; Langlois, V.; Kelly, F. J. Microplastics in air: Are we breathing it in? Curr. Opin. Environ. Sci. Health 2018, 1, 1-5.

(127) van Pomeren, M.; Brun, N. R.; Peijnenburg, W. J. G. M.; Vijver, M. G. Exploring uptake and biodistribution of polystyrene (nano)particles in zebrafish embryos at different developmental stages. Aquat. Toxicol. 2017, 190, 40-45.

(128) Cole, M.; Galloway, T. S. Ingestion of Nanoplastics and Microplastics by Pacific Oyster Larvae. Environ. Sci. Technol. 2015, 49 (24), 14625-14632.

(129) Li, W. C.; Tse, H. F.; Fok, L. Plastic waste in the marine environment: A review of sources, occurrence and effects. Sci. Total Environ. 2016, 566-567, 333-349.

(130) Yaka, M.; Ehirchiou, A.; Alkandry, T. T. S.; Sair, K. Huge plastic bezoar: a rare cause of gastrointestinal obstruction. Pan Afr. Med. J. 2015, 21, 286.

(131) EFSA Panel on Contaminants in the Food Chain (CONTAM). Presence of microplastics and nanoplastics in food, with particular focus on seafood. EFSA J. 2016, 14 (6), e04501.

(132) Forte, M.; Iachetta, G.; Tussellino, M.; Carotenuto, R.; Prisco, M.; De Falco, M.; Laforgia, V.; Valiante, S. Polystyrene nanoparticles internalization in human gastric adenocarcinoma cells. Toxicol. In Vitro 2016, 31, 126-136.

(133) Walczak, A. P.; Kramer, E.; Hendriksen, P. J. M.; Tromp, P.; Helsper, J. P. F. G.; van der Zande, M.; Rietjens, I. M. C. M.; Bouwmeester, H. Translocation of differently sized and charged polystyrene nanoparticles in in vitro intestinal cell models of increasing complexity. Nanotoxicology 2015, 9 (4), 453-461.

(134) Mahler, G. J.; Esch, M. B.; Tako, E.; Southard, T. L.; Archer, S. D.; Glahn, R. P.; Shuler, M. L. Oral exposure to polystyrene nanoparticles affects iron absorption. Nat. Nanotechnol. 2012, 7 (4), 264-271.

(135) Mahmoudi, M.; Lynch, I.; Ejtehadi, M. R.; Monopoli, M. P.; Bombelli, F. B.; Laurent, S. Protein-nanoparticle interactions: opportunities and challenges. Chem. Rev. 2011, 111 (9), 5610-5637.

(136) Treuel, L.; Brandholt, S.; Maffre, P.; Wiegele, S.; Shang, L.; Nienhaus, G. U. Impact of Protein Modification on the Protein Corona on Nanoparticles and Nanoparticle-Cell Interactions. ACS Nano 2014, 8 (1), 503-513.

(137) Walczak, A. P.; Kramer, E.; Hendriksen, P. J. M.; Helsdingen, R.; van der Zande, M.; Rietjens, I. M. C. M.; Bouwmeester, H. In vitro gastrointestinal digestion increases the translocation of polystyrene nanoparticles in an in vitro intestinal co-culture model. Nanotoxicology 2015, 9 (7), 886-894.

(138) Tenzer, S.; Docter, D.; Kuharev, J.; Musyanovych, A.; Fetz, V.; Hecht, R.; Schlenk, F.; Fischer, D.; Kiouptsi, K.; Reinhardt, C.; et al. Rapid formation of plasma protein corona critically affects nanoparticle pathophysiology. Nat. Nanotechnol. 2013, 8 (10), 772-781.
(139) Nasser, F.; Lynch, I. Secreted protein eco-corona mediates uptake and impacts of polystyrene nanoparticles on Daphnia magna. J. Proteomics 2016, 137, 45-51.

(140) Schneider, M.; Stracke, F.; Hansen, S.; Schaefer, U. F. Nanoparticles and their interactions with the dermal barrier. Derm. Endocrinol. 2009, 1 (4), 197-206.

(141) Alvarez-Román, R.; Naik, A.; Kalia, Y. N.; Guy, R. H.; Fessi, $\mathrm{H}$. Skin penetration and distribution of polymeric nanoparticles. $J$. Controlled Release 2004, 99 (1), 53-62.

(142) Campbell, C. S. J.; Contreras-Rojas, L. R.; Delgado-Charro, M. B.; Guy, R. H. Objective assessment of nanoparticle disposition in mammalian skin after topical exposure. J. Controlled Release 2012, 162 (1), 201-207.

(143) Vogt, A.; Combadiere, B.; Hadam, S.; Stieler, K. M.; Lademann, J.; Schaefer, H.; Autran, B.; Sterry, W.; Blume-Peytavi, U. $40 \mathrm{~nm}$, but not 750 or $1,500 \mathrm{~nm}$, nanoparticles enter epidermal $\mathrm{CD} 1 \mathrm{a}+$ cells after transcutaneous application on human skin. J. Invest. Dermatol. 2006, 126 (6), 1316-1322.

(144) Mortensen, L. J.; Oberdörster, G.; Pentland, A. P.; Delouise, L. A. In vivo skin penetration of quantum dot nanoparticles in the murine model: the effect of UVR. Nano Lett. 2008, 8 (9), 2779-2787.

(145) Jatana, S.; Callahan, L. M.; Pentland, A. P.; Delouise, L. A. Impact of Cosmetic Lotions on Nanoparticle Penetration through ex vivo C57BL/6 Hairless Mouse and Human Skin: A Comparison Study. Cosmetics 2016, 3 (1), 6.

(146) Lane, M. E. Skin penetration enhancers. Int. J. Pharm. 2013, 447 (1-2), 12-21.

(147) Kuo, T.-R.; Wu, C.-L.; Hsu, C.-T.; Lo, W.; Chiang, S.-J.; Lin, S.-J.; Dong, C.-Y.; Chen, C.-C. Chemical enhancer induced changes in the mechanisms of transdermal delivery of zinc oxide nanoparticles. Biomaterials 2009, 30 (16), 3002-3008.

(148) Bouwstra, J.; Pilgram, G.; Gooris, G.; Koerten, H.; Ponec, M. New aspects of the skin barrier organization. Skin Pharmacol. Appl. Skin Physiol. 2001, 14 (1), 52-62.

(149) Anselmo, A. C.; Gupta, V.; Zern, B. J.; Pan, D.; Zakrewsky, M.; Muzykantov, V.; Mitragotri, S. Delivering Nanoparticles to Lungs while Avoiding Liver and Spleen through Adsorption on Red Blood Cells. ACS Nano 2013, 7 (12), 11129-11137.

(150) Chambers, E.; Mitragotri, S. Prolonged circulation of large polymeric nanoparticles by non-covalent adsorption on erythrocytes. J. Controlled Release 2004, 100 (1), 111-119.

(151) Grafmueller, S.; Manser, P.; Diener, L.; Diener, P.-A.; MaederAlthaus, X.; Maurizi, L.; Jochum, W.; Krug, H. F.; Buerki-Thurnherr, T.; von Mandach, U.; et al. Bidirectional Transfer Study of Polystyrene Nanoparticles across the Placental Barrier in an ex Vivo Human Placental Perfusion Model. Environ. Health Perspect. 2015, 123 (12), 1280-1286.

(152) Yang, C.-S.; Chang, C.-H.; Tsai, P.-J.; Chen, W.-Y.; Tseng, F.G.; Lo, L.-W. Nanoparticle-Based in Vivo Investigation on BloodBrain Barrier Permeability Following Ischemia and Reperfusion. Anal. Chem. 2004, 76 (15), 4465-4471.

(153) Rafiee, M.; Dargahi, L.; Eslami, A.; Beirami, E.; Jahangiri-Rad, M.; Sabour, S.; Amereh, F. Neurobehavioral assessment of rats exposed to pristine polystyrene nanoplastics upon oral exposure. Chemosphere 2018, 193, 745-753.

(154) Krug, H. F.; Wick, P. Nanotoxicology: An Interdisciplinary Challenge. Angew. Chem., Int. Ed. 2011, 50 (6), 1260-1278.

(155) Doherty, G. J.; McMahon, H. T. Mechanisms of Endocytosis. Annu. Rev. Biochem. 2009, 78, 857-902.

(156) Khalil, I.; Kogure, K.; Akita, H.; Harashima, H. Uptake pathways and subsequent intracellular trafficking in nonviral gene delivery. Pharmacol Rev. 2006, 58 (1), 32-45.

(157) Ziello, J.; Huang, Y. Cellular Endocytosis and Gene Delivery. Mol. Med. 2010, 16 (5-6), 1.

(158) Rossi, G.; Barnoud, J.; Monticelli, L. Polystyrene Nanoparticles Perturb Lipid Membranes. J. Phys. Chem. Lett. 2014, 5 (1), 241-246.

(159) Fiorentino, I.; Gualtieri, R.; Barbato, V.; Mollo, V.; Braun, S.; Angrisani, A.; Turano, M.; Furia, M.; Netti, P. A.; Guarnieri, D.; et al. 
Energy independent uptake and release of polystyrene nanoparticles in primary mammalian cell cultures. Exp. Cell Res. 2015, 330 (2), 240-247.

(160) dos Santos, T.; Varela, J.; Lynch, I.; Salvati, A.; Dawson, K. A. Effects of transport inhibitors on the cellular uptake of carboxylated polystyrene nanoparticles in different cell lines. PLoS One 2011, 6 (9), No. e24438.

(161) Wang, T.; Bai, J.; Jiang, X.; Nienhaus, G. U. Cellular uptake of nanoparticles by membrane penetration: a study combining confocal microscopy with FTIR spectroelectrochemistry. ACS Nano 2012, 6 (2), 1251-1259.

(162) Geiser, M.; Rothen-Rutishauser, B.; Kapp, N.; Schürch, S.; Kreyling, W.; Schulz, H.; Semmler, M.; Hof, V. I.; Heyder, J.; Gehr, P. Ultrafine particles cross cellular membranes by nonphagocytic mechanisms in lungs and in cultured cells. Environ. Health Perspect. 2005, 113 (11), 1555-1560.

(163) Rothen-Rutishauser, B. M.; Schürch, S.; Haenni, B.; Kapp, N.; Gehr, P. Interaction of fine particles and nanoparticles with red blood cells visualized with advanced microscopic techniques. Environ. Sci. Technol. 2006, 40 (14), 4353-4359.

(164) Fazlollahi, F.; Angelow, S.; Yacobi, N. R.; Marchelletta, R.; Yu, A. S. L.; Hamm-Alvarez, S. F.; Borok, Z.; Kim, K.-J.; Crandall, E. D. Polystyrene nanoparticle trafficking across MDCK-II. Nanomedicine 2011, 7 (5), 588-594.

(165) Kuhn, D. A.; Vanhecke, D.; Michen, B.; Blank, F.; Gehr, P.; Petri-Fink, A.; Rothen-Rutishauser, B. Different endocytotic uptake mechanisms for nanoparticles in epithelial cells and macrophages. Beilstein J. Nanotechnol. 2014, 5 (1), 1625-1636.

(166) Koelmans, A. A.; Besseling, E.; Wegner, A.; Foekema, E. M. Plastic as a carrier of POPs to aquatic organisms: a model analysis. Environ. Sci. Technol. 2013, 47 (14), 7812-7820.

(167) Fröhlich, E.; Meindl, C.; Roblegg, E.; Ebner, B.; Absenger, M.; Pieber, T. R. Action of polystyrene nanoparticles of different sizes on lysosomal function and integrity. Part. Fibre Toxicol. 2012, 9 (1), 26.

(168) Isidoro, C.; Maneerat, E.; Giovia, A.; Follo Carlo; Caputo, G. Biocompatibility, endocytosis, and intracellular trafficking of mesoporous silica and polystyrene nanoparticles in ovarian cancer cells: effects of size and surface charge groups. Int. J. Nanomed. 2012, 7, 4147-4158.

(169) Fröhlich, E. The role of surface charge in cellular uptake and cytotoxicity of medical nanoparticles. Int. J. Nanomed. 2012, 7, 55775591.

(170) Malek, A.; Merkel, O.; Fink, L.; Czubayko, F.; Kissel, T.; Aigner, A. In vivo pharmacokinetics, tissue distribution and underlying mechanisms of various PEI(-PEG)/siRNA complexes. Toxicol. Appl. Pharmacol. 2009, 236 (1), 97-108.

(171) Elsaesser, A.; Howard, C. V. Toxicology of nanoparticles. Adv. Drug Delivery Rev. 2012, 64 (2), 129-137.

(172) Brown, D. M.; Wilson, M. R.; MacNee, W.; Stone, V.; Donaldson, K. Size-dependent proinflammatory effects of ultrafine polystyrene particles: a role for surface area and oxidative stress in the enhanced activity of ultrafines. Toxicol. Appl. Pharmacol. 2001, 175 (3), 191-199.

(173) McCarthy, J.; Gong, X.; Nahirney, D.; Duszyk, M.; Radomski, M. Polystyrene nanoparticles activate ion transport in human airway epithelial cells. Int. J. Nanomed. 2011, 6, 1343-1356.

(174) Fuchs, A.-K.; Syrovets, T.; Haas, K. A.; Loos, C.; Musyanovych, A.; Mailänder, V.; Landfester, K.; Simmet, T. Carboxyland amino-functionalized polystyrene nanoparticles differentially affect the polarization profile of M1 and M2 macrophage subsets. Biomaterials 2016, 85, 78-87.

(175) Barshtein, G.; Livshits, L.; Shvartsman, L. D.; Shlomai, N. O.; Yedgar, S.; Arbell, D. Polystyrene Nanoparticles Activate Erythrocyte Aggregation and Adhesion to Endothelial Cells. Cell Biochem. Biophys. 2016, 74 (1), 19-27.

(176) Barbul, A.; Singh, K.; Horev-Azaria, L.; Dasgupta, S.; Auth, T.; Korenstein, R.; Gompper, G. Nanoparticle-Decorated Erythrocytes Reveal That Particle Size Controls the Extent of Adsorption, Cell
Shape, and Cell Deformability. ACS Applied Nano Materials 2018, 1 (8), 3785-3799.

(177) Xia, L.; Gu, W.; Zhang, M.; Chang, Y.-N.; Chen, K.; Bai, X.; Yu, L.; Li, J.; Li, S.; Xing, G. Endocytosed nanoparticles hold endosomes and stimulate binucleated cells formation. Part. Fibre Toxicol. 2016, 13 (1), 63.

(178) Inkielewicz-Stepniak, I.; Tajber, L.; Behan, G.; Zhang, H.; Radomski, M. W.; Medina, C.; Santos-Martinez, M. J. The Role of Mucin in the Toxicological Impact of Polystyrene Nanoparticles. Materials 2018, 11 (5), 724.

(179) Chiu, H.-W.; Xia, T.; Lee, Y.-H.; Chen, C.-W.; Tsai, J.-C.; Wang, Y.-J. Cationic polystyrene nanospheres induce autophagic cell death through the induction of endoplasmic reticulum stress. Nanoscale 2015, 7 (2), 736-746.

(180) Xia, T.; Kovochich, M.; Liong, M.; Zink, J. I.; Nel, A. E. Cationic polystyrene nanosphere toxicity depends on cell-specific endocytic and mitochondrial injury pathways. ACS Nano 2008, 2 (1), $85-96$.

(181) Liu, X.; Tian, X.; Xu, X.; Lu, J. Design of a phosphinate-based bioluminescent probe for superoxide radical anion imaging in living cells. Luminescence 2018, 33 (6), 1101-1106.

(182) Green, T. R.; Fisher, J.; Stone, M.; Wroblewski, B. M.; Ingham, E. Polyethylene particles of a "critical size" are necessary for the induction of cytokines by macrophages in vitro. Biomaterials 1998, 19 (24), 2297-2302.

(183) Veruva, S. Y.; Lanman, T. H.; Isaza, J. E.; Freeman, T. A.; Kurtz, S. M.; Steinbeck, M. J. Periprosthetic UHMWPE Wear Debris Induces Inflammation, Vascularization, and Innervation after Total Disc Replacement in the Lumbar Spine. Clin. Orthop. Relat. Res. 2017, 475, 1369-1381.

(184) Suñer, S.; Gowland, N.; Craven, R.; Joffe, R.; Emami, N.; Tipper, J. L. Ultrahigh molecular weight polyethylene/graphene oxide nanocomposites: Wear characterization and biological response to wear particles. J. Biomed. Mater. Res., Part B 2018, 106 (1), 183-190.

(185) Massin, P.; Achour, S. Wear products of total hip arthroplasty: The case of polyethylene. Morphologie 2017, 101, 1-8.

(186) Nich, C.; Goodman, S. B. Role of macrophages in the biological reaction to wear debris from joint replacements. J. LongTerm Eff. Med. Implants 2014, 24 (4), 259-265.

(187) Devane, P. A.; Bourne, R. B.; Rorabeck, C. H.; Hardie, R. M.; Home, J. G. Measurement of Polyethylene Wear in Metal-Backed Acetabular Cups: I. Three-Dimensional Technique. Clin. Orthop. Relat. Res. 1995, 319, 303-316.

(188) Shanbhag, A. S.; Jacobs, J. J.; Glant, T. T.; Gilbert, J. L.; Black, J.; Galante, J. O. Composition and morphology of wear debris in failed uncemented total hip replacement. J. Bone Jt. Surg., Br. Vol. 1994, 76-B (1), 60-67.

(189) Magrì, D.; Sánchez-Moreno, P.; Caputo, G.; Gatto, F.; Veronesi, M.; Bardi, G.; Catelani, T.; Guarnieri, D.; Athanassiou, A.; Pompa, P. P.; et al. Laser Ablation as a Versatile Tool To Mimic Polyethylene Terephthalate Nanoplastic Pollutants: Characterization and Toxicology Assessment. ACS Nano 2018, 12 (8), 7690-7700.

(190) Thubagere, A.; Reinhard, B. M. Nanoparticle-induced apoptosis propagates through hydrogen-peroxide-mediated bystander killing: insights from a human intestinal epithelium in vitro model. ACS Nano 2010, 4 (7), 3611-3622.

(191) Ruenraroengsak, P.; Tetley, T. D. Differential bioreactivity of neutral, cationic and anionic polystyrene nanoparticles with cells from the human alveolar compartment: robust response of alveolar type 1 epithelial cells. Part. Fibre Toxicol. 2015, 12 (1), 19.

(192) Paget, V.; Dekali, S.; Kortulewski, T.; Grall, R.; Gamez, C.; Blazy, K.; Aguerre-Chariol, O.; Chevillard, S.; Braun, A.; Rat, P.; et al. Specific uptake and genotoxicity induced by polystyrene nanobeads with distinct surface chemistry on human lung epithelial cells and macrophages. PLoS One 2015, 10 (4), No. e0123297.

(193) Lunov, O.; Syrovets, T.; Loos, C.; Beil, J.; Delacher, M.; Tron, K.; Nienhaus, G. U.; Musyanovych, A.; Mailänder, V.; Landfester, K.; et al. Differential uptake of functionalized polystyrene nanoparticles 
by human macrophages and a monocytic cell line. ACS Nano 2011, 5 (3), 1657-1669.

(194) Prietl, B.; Meindl, C.; Roblegg, E.; Pieber, T. R.; Lanzer, G.; Fröhlich, E. Nano-sized and micro-sized polystyrene particles affect phagocyte function. Cell Biol. Toxicol. 2014, 30 (1), 1-16.

(195) Firdessa, R.; Oelschlaeger, T. A.; Moll, H. Identification of multiple cellular uptake pathways of polystyrene nanoparticles and factors affecting the uptake: Relevance for drug delivery systems. Eur. J. Cell Biol. 2014, 93 (8-9), 323-337.

(196) Monti, D. M.; Guarnieri, D.; Napolitano, G.; Piccoli, R.; Netti, P.; Fusco, S.; Arciello, A. Biocompatibility, uptake and endocytosis pathways of polystyrene nanoparticles in primary human renal epithelial cells. J. Biotechnol. 2015, 193, 3-10.

(197) Johnston, H. J.; Semmler-Behnke, M.; Brown, D. M.; Kreyling, W.; Tran, L.; Stone, V. Evaluating the uptake and intracellular fate of polystyrene nanoparticles by primary and hepatocyte cell lines in vitro. Toxicol. Appl. Pharmacol. 2010, 242 (1), 66-78.

(198) Zauner, W.; Farrow, N. A.; Haines, A. M. R. In vitro uptake of polystyrene microspheres: effect of particle size, cell line and cell density. J. Controlled Release 2001, 71 (1), 39-51.

(199) Jiang, X.; Musyanovych, A.; Röcker, C.; Landfester, K.; Mailänder, V.; Nienhaus, G. U. Specific effects of surface carboxyl groups on anionic polystyrene particles in their interactions with mesenchymal stem cells. Nanoscale 2011, 3 (5), 2028-2035.

(200) Kang, T.; Park, C.; Lee, B.-J. Investigation of biomimetic shear stress on cellular uptake and mechanism of polystyrene nanoparticles in various cancer cell lines. Arch. Pharmacal Res. 2016, 39 (12), $1663-1670$.

(201) Ter Halle, A.; Jeanneau, L.; Martignac, M.; Jardé, E.; Pedrono, B.; Brach, L.; Gigault, J. Nanoplastic in the North Atlantic Subtropical Gyre. Environ. Sci. Technol. 2017, 51 (23), 13689-13697.

(202) Chang, C.-I. Hyperspectral Measures for Spectral Characterization. Hyperspectral Imaging; Springer: Boston, MA, USA, 2003; pp 15-35, DOI: $10.1007 / 978-1-4419-9170-6$ _2.

(203) Khan, M. J.; Khan, H. S.; Yousaf, A.; Khurshid, K.; Abbas, A. Modern Trends in Hyperspectral Image Analysis: A Review. IEEE Access 2018, 6, 14118-14129.

(204) Serranti, S.; Palmieri, R.; Bonifazi, G.; Cozar, A. Characterization of microplastic litter from oceans by an innovative approach based on hyperspectral imaging. Waste Manage. 2018, 76, 117-125. (205) Shan, J.; Zhao, J.; Liu, L.; Zhang, Y.; Wang, X.; Wu, F. A novel way to rapidly monitor microplastics in soil by hyperspectral imaging technology and chemometrics. Environ. Pollut. 2018, 238, 121-129.

(206) Correia, M.; Loeschner, K. Detection of nanoplastics in food by asymmetric flow field-flow fractionation coupled to multi-angle light scattering: possibilities, challenges and analytical limitations. Anal. Bioanal. Chem. 2018, 410 (22), 5603-5615.

(207) Huth, F.; Govyadinov, A.; Amarie, S.; Nuansing, W.; Keilmann, F.; Hillenbrand, R. Nano-FTIR absorption spectroscopy of molecular fingerprints at $20 \mathrm{~nm}$ spatial resolution. Nano Lett. 2012, 12 (8), 3973-3978.

(208) Dazzi, A.; Prater, C. B.; Hu, Q.; Chase, D. B.; Rabolt, J. F.; Marcott, C. AFM-IR: combining atomic force microscopy and infrared spectroscopy for nanoscale chemical characterization. Appl. Spectrosc. 2012, 66 (12), 1365-1384.

(209) Chernenko, T.; Buyukozturk, F.; Miljkovic, M.; Carrier, R.; Diem, M.; Amiji, M. Label-Free Raman Microspectral Analysis for Comparison of Cellular Uptake and Distribution between NonTargeted and EGFR-Targeted Biodegradable Polymeric Nanoparticles. Drug Delivery Transl. Res. 2013, 3 (6), 575-586. 